\title{
Assessment and economic valuation of air pollution impacts on human health over Europe and the United States as calculated by a multi-model ensemble in the framework of AQMEII3
}

Ulas Im et al.

Correspondence to: Ulas Im (ulas@envs.au.dk)

The copyright of individual parts of the supplement might differ from the CC BY 4.0 License. 


\section{Model Features}

The FMI (Finnish Meteorological Institute: FI1) used the SILAM v5.4 (Sofiev et al., 2015) model, driven by the meteorological input extracted from the ECMWF operational archives. The simulation included sea salt emissions as in Sofiev et al. (2011) (but not from the boundaries), biogenic VOCs (volatile organic compounds) emissions as in Poupkou et al. (2010), and wildland fire emissions as in Soares et al. (2015). The windblown dust is only included from the lateral boundary conditions. The volatility distribution of anthropogenic organic carbon (OC) was taken from Shrivastava et al. (2011). The gasphase chemistry was simulated with CBM-IV, with reaction rates updated according to the recommendations of International Union of Pure and Applied Chemistry (IUPAC) (http: //iupac.pole-ether.fr) and the NASA Jet Propulsion Laboratory (JPL) (http://jpldataeval.jpl.nasa.gov). The secondary inorganic aerosol formation was computed with the updated DMAT scheme (Sofiev, 2000) and secondary organic aerosol formation with the volatility basis set (VBS; Ahmadov et al., 2012). Pressure- and latitude-dependent photolysis rates of the FinROSE model (Damski et al., 2007) are used and reduced proportionally to cloud cover below the clouds down to half the original value at full cloud cover. The SILAM model does not account for extra plume rise in addition to that prescribed by the emission profiles. A known deficiency of the SILAM version used in this study is the overestimation of ozone dry deposition.

TNO (the Netherlands Organisation for Applied Scientific Research- NL1) used the LOTOSEUROS modeling system (Schaap et al., 2008, Sauter et al., 2012). The meteorological inputs were extracted from the ECMWF operational archives. For biogenic emissions the approach as described in Beltman et al. (2013) was used. Gas-phase chemistry is based on CBM-IV (modified reaction rates; see Sauter et al., 2012), secondary inorganic aerosol (SIA) formation on ISORROPIA II (Fountoukis and Nenes, 2009), and for semivolatile species the VBS approach was used (Donahue et al., 2006; Bergström et al., 2012), with 100\% of the emitted OC mass in the four lowest volatility classes that are predominantly solid and an additional $150 \%$ in the five higher volatility bins. Modeled terpene emissions were reduced by $50 \%$ to limit their contribution to SOA (secondary organic aerosol) formation, which was found to be too high otherwise (Bergström et al., 2012). No NOx emissions from soil were taken into account. The model includes pH-dependent conversion rates for SO2 (Banzhaf et al., 2012), while only below-cloud scavenging is used for wet deposition. Mineral dust emissions were calculated online, including emissions from road resuspension and agricultural activities, according to Schaap et al. (2009). For sea spray the parameterizations by Monahan et al. (1986) and Martensson et al. (2003) were used. Photolysis rates are based on clear-sky photolysis rate by Roeth's flux algorithm (function of solar zenith angle; Poppe et al., 1996) and multiplied by an attenuation factor in case of clouds. The LOTOS-EUROS model does not account for extra plume rise in addition to that prescribed by the emission profiles. A specific feature of LOTOSEUROS is that it only covers the lower $3.5 \mathrm{~km}$ of the atmosphere, with a static $25 \mathrm{~m}$ surface layer, a dynamic mixing layer and two dynamic reservoir layers. This makes the model relatively fast in terms of computation time but has implications for the vertical mixing of species for instances where the mixing layer rapidly changes in height. 
The INERIS and CIEMAT institutes jointly (FRES1) applied the ECMWF-CHIMERE system. CHIMERE (version CHIMERE 2013) was run with meteorology provided by ECMWF IFS. Biogenic VOC emissions from vegetation and soil NO emissions were calculated with the MEGAN model (version 2.04; Guenther et al., 2006, 2012). Sea salt emissions inside the domain were calculated according to Monahan (1986). The windblown dust is only included from the lateral boundary conditions. CHIMERE uses the MELCHIOR2 chemical mechanism (Lattuati, 1997), and ammonium nitrate equilibrium was calculated with ISORROPIA (Nenes et al., 1999). Dry deposition is based on the resistance approach (Emberson 2000a, b) and both in-cloud and sub-cloud scavenging were considered for wet deposition.

University of L'Aquila (IT1) used the Weather Research and Forecasting model with Chemistry (WRF-Chem) Version 3.6, which has been modified to include the new chemistry option implemented by Tuccella et al. (2015) that includes a better representation of the secondary organic aerosol mass in the simulation of direct and indirect aerosol effects, calculated as in Ahmadov et al. (2012). Here only direct effects were included in the simulation, for computational expediency. The model uses the RACM-ESRL gas-phase chemical mechanism (Kim et al., 2009), an updated version of the Regional Atmospheric Chemistry Mechanism (RACM; Stockwell et al., 1997). The inorganic aerosols are treated with the Modal Aerosol Dynamics model for Europe (MADE; Ackermann et al., 1998). The parameterization for SOA production is based on the volatility basis set (VBS) approach. The aerosol direct and semi-direct effects are taken into account following Fast et al. (2006). Cloud chemistry in the convective updraft is modeled using the scheme of Walcek and Taylor (1986), while the aqueous-phase oxidation of SO2 by $\mathrm{H} 2 \mathrm{O} 2$ in the grid-resolved clouds is parameterized with the scheme used in GOCART (Goddard Chemistry Aerosol Radiation and Transport).Wet deposition from convective and resolved precipitation is included following Grell and Freitas (2014). The photolysis frequencies are calculated with the Fast-J scheme (Fast et al., 2006). Dry deposition and photolysis schemes were modified to take into account the effects of the soil snow coverage following Ahmadov et al. (2015).

University of Murcia (ES1) used the WRFChem2 model. The following physics options were applied for the simulations: rapid radiative transfer method for global (RRTMG) long-wave and shortwave radiation scheme, Lin microphysics (Lin et al., 1993), the Yonsei University (YSU) PBL scheme (Hong et al., 2006), the NOAH land-surface model, and the updated version of the Grell-Devenyi scheme (Grell and Devenyi, 2002) with radiative feedback. Chemical options include RADM2 chemical mechanism (Stockwell et al., 1990), MADE/SORGAM aerosol module (Schell et al., 2001) including some aqueous reactions, and Fast-J photolysis scheme. The modeling domain covers Europe and a portion of North Africa.

RSE (IT2) used WRF-CAMx version 6.10 (Environ, 2014) with Carbon Bond 2005 (CB05) gas-phase chemistry (Yarwood et al., 2005) and the coarse-fine (CF) aerosol module. Input meteorological data were generated by WRF model version 3.4.1 (Skamarock et al., 2008), driven by ECMWF analysis fields. Grid nudging of wind speed, temperature, and water vapor mixing ratio was employed within the PBL, with a nudging coefficient of $0.0003 \mathrm{~s}^{-1}$. WRFChem was adopted to predict GOCART dust emissions (Ginoux et al., 2001) along with the meteorology.The WRF-CAMx preprocessor (version 4.2; Environ, 2014) was used to create 
CAMx ready input files, collapsing the 33 vertical layers used by WRF into 14 layers in CAMx but keeping the layers up to 230m above ground level identical. Biogenic VOC emissions were computed by applying the MEGAN emission model v2.04. Sea salt emissions were computed using published algorithms (de Leeuw et al., 2000; Gong, 2003).

Aarhus University (DE1) applied the WRF-DEHM modeling system over EU and NA. The DEHM model used anthropogenic emissions from the EDGAR-HTAP database and biogenic emissions were calculated using the MEGAN model. The gas-phase chemistry module includes 58 chemical species, 9 primary particles, and 122 chemical reactions (Brandt et al., 2012). Secondary organic aerosols (SOA) were calculated following the two-product approach assuming that hydrocarbons undergo oxidation through $\mathrm{O} 3, \mathrm{OH}$, and $\mathrm{NO} 3$ and for only two semi-volatile gas products (Zare et al., 2014). However, the module is simple because it does not include aging processes and further reactions in the gas and particulate phases (Zare et al., 2014).

Istanbul Technical University (TR1) used the WRF-CMAQ. The Meteorology-Chemistry Interface Processor (MCIP) version 3.6 (Otte and Pleim, 2010) was used to process WRF output for CMAQ. The MEGAN v2.1 (Guenther et al., 2012) model was used to calculate the biogenic VOC emissions from vegetation, using surface temperature and radiation from MCIP output. CMAQ v4.7.1 (Foley et al., 2010) was configured with the CB05 chemical mechanism and the AERO5 module (Foley et al., 2010) for the simulation of gas-phase chemistry and aerosol and aqueous chemistry, respectively.

Ricardo Energy \& Environment (Ricardo E\&E: UK2) used the WRF-CMAQ system. It was configured using WRF v3.5.1 and CMAQ v5.0.2. The CMAQ model adopted the CB05-TUCL chemical mechanism (Whitten et al., 2010; Sarwar et al., 2011) and the AERO6 threemode aerosol module (Appel et al., 2013). MCIP version 4.2 was used to process WRF output for CMAQ. The MEGAN v2.0.4 model was used to calculate the biogenic VOC emissions from vegetation, using surface temperature and radiation from MCIP output.

University of Hertfordshire (UK1) used the WRF-CMAQ modeling system utilized the uncoupled version of the WRF v3.4.1 model and CMAQ v5.0.2. The results from WRF simulations were preprocessed for CMAQ using MCIP version 3.6 (Otte et al., 2005). In the CMAQ model, the gas-phase chemical mechanism was based on Carbon Bond chemical mechanism version 5 (Foley et al., 2010) with updated toluene and chlorine chemistry (CB05TUCL), and the aerosol chemical reaction was treated with AERO6 module. The biogenic emissions were derived from MEGAN.

Kings College (UK3) used the WRF-CMAQ model, using CMAQ v5.0.2 (Byun and Schere, 2006), with CB05 chemical mechanism that included aqueous and aerosol chemistry. The CMAQ model is driven by meteorological fields from WRF v3.4.1. The anthropogenic emissions for most of the model domain are from MACC and the missing information was filled with the emissions provided by EDGAR/HTAP. The biogenic emissions were estimated using the BEIS3 model. The dust and sea salt (Gantt et al., 2015) emissions were generated using CMAQ inline modules. 
HZG (DE1) used the COSMO-CLM meteorological model to drive the CMAQ model. For AQMEII3, CMAQ version 5.0.1 was used, with the CB05-TUCL scheme and the multipollutant aerosol module AERO6. CMAQ was run using the optional in-line calculation of dry deposition velocities. Wet deposition processes include in-cloud and sub-cloud scavenging processes. All atmospheric parameters were taken from regional atmospheric simulations with the COSMOCLM (CCLM) mesoscale meteorological model (version 4.8) for the year 2010 (Geyer, 2014) using National Centers for Environmental Prediction (NCEP) forcing data employing a spectral nudging method for large-scale effects (Kalnay et al., 1996). CCLM is the climate version of the regionalscale meteorological community model COSMO (Schaettler et al., 2008). CCLM uses the TERRA-ML land surface model (Schrodin and Heise, 2001), a turbulent kinetic energy (TKE) closure scheme for the PBL (Doms et al., 2011), cloud microphysics after Seifert and Beheng (2001), the Tiedtke scheme (Tiedtke, 1989) for cumulus clouds, and a long-wave radiation scheme following Ritter and Geleyn (1992). The meteorological fields were processed afterwards to match the $2424 \mathrm{~km} 2$ CMAQ grid using the LM-MCIP preprocessor. The emission input for CCLM-CMAQ is based on the EDGAR HTAPv2 database, interpolated to the CMAQ model grid and aggregated following the SNAP emission sector nomenclature. Sector-specific hourly temporal profiles and speciation factors of PM and VOC species were applied by the SMOKE for Europe emissions model (Bieser et al., 2011a). The temporal profiles used were fixed monthly, weekly, and diurnal profiles. Biogenic emissions and NO emissions from soil were calculated using the BEIS3 model. Sea salt emissions were calculated in-line by CMAQ, including sulfate emissions based on an average sulfate content of $7.7 \%$. Finally, fixed vertical profiles were applied for each source sector (Bieser et al., 2011b).

US EPA (US3) used the WRF-CMAQ system over NA and was configured using WRF v3.4 and CMAQ v5.0.2 (Appel et al., 2013; see also Foley et al., 2010 and Byun and Schere, 2006). The options used in these WRF and CMAQ simulations are identical to those described in Hogrefe et al. (2015), except that the current simulations were performed in offline rather than two-way coupled mode. Temperature, wind speed, and water vapor mixing ratio were nudged above the PBL following the approach described in Gilliam et al. (2012). Soil temperature and moisture were nudged following Pleim and Xiu (2003) and Pleim and Gilliam (2009). The NO2 =NOx split applied during SMOKE emission processing varies for different categories. For many categories the assumed split is $90 \% \mathrm{NO}=10 \% \mathrm{NO} 2$, but for mobile sources the split varies for different types of vehicles and different emission processes.

\section{Model Evaluation}

The models are evaluated against the surface observations using normalized mean bias $(N M B)$, normalized mean gross error (NMGE), root mean square error (RMSE) and correlation coefficient $(r)$.

$N M B=\frac{\sum_{i=1}^{n}|M i-O i|}{\sum_{i=1}^{n} O i}$ 
$N M G E=\frac{\sum_{i=1}^{n}|M i-O i|}{\sum_{i=1}^{n} O i}$

Eq.2

$R M S E=\sqrt{\frac{\sum_{i=1}^{n}(M i-O i)^{2}}{n}}$

$r=\frac{1}{(n-1)} \sum_{i=1}^{n}\left(\frac{M i-\bar{M}}{\sigma_{M}}\right)\left(\frac{O i-\bar{O}}{\sigma_{O}}\right)$

Eq.4

where $M$ and $O$ denote model and observations, while $n$ denotes number of pairs.

\section{Sensitivity Analysis of EVA}

The effect of pollution concentrations (EVA input) on health impacts (EVA output) is investigated by means of pairwise regression analysis. The input dataset consists of the simulated pollutant by each model, averaged over all stations. The averaging was performed at 9 discrete percentiles $(1,5,10,25,50,75,90,95$, and 99). The output dataset consists of the 14 health impact indices for each model. The Pearson Correlation Coefficient (PCC) between the simulated pollutant levels and health impacts are presented in Fig. S1 (X axis: the 9 percentiles, Y axis: PCC) as boxplot. The spread at each percentile marks the variability of PCC between the different health impact indices (HII). For the particular input-output configuration, the results show that the $\mathrm{PM}_{2.5}$ drives the variability of the HIIs, with PCC in the range $0.75-0.88$ for all percentiles except the $1^{\text {st }}(0.63)$. All correlations are statistically significant. For the other pollutants, the correlations are mostly statistically non-significant.

More quantitative measures of sensitivity are evaluated from the standardized regression coefficients (SRCs). Assume bj is the linear regression coefficient of the dependent input $\mathrm{xj}$ $\left(\mathrm{O}_{3}, \mathrm{PM}_{2.5}, \mathrm{SO}_{2}, \mathrm{CO}\right)$ and the independent variable y (health indices) using a multiple linear regression model. If $\sigma x j$ and $\sigma y$ represent the standard deviations of the dependent input $x j$ and the independent variable y respectively, the SRCs are defined as bjoxj/oy. The SRCs offer a measure of sensitivity that is multi-dimensionally averaged and hence represent a global measure of sensitivity. The effectiveness of the standardized regression coefficients is conditional on the value of the model coefficient of determination $\left(\mathrm{R}^{2}\right)$. The fit of the regression (Table S1) is high (0.76-0.96), implying that the linear regression model is able to represent the majority of the variation of the HII. This also means that at least $76 \%$ of the variation of the health indices is explained by sole variations in the pollutants (i.e. without interactions). If all pollutants take extreme low values, $\mathrm{O}_{3}$ has the largest effect on health indices. Within the interquartile range of the pollutants, the most important contribution to the HIIs is from $\mathrm{PM}_{2.5}$, followed by $\mathrm{CO}$ (with much smaller influence though). At the upper tail of the pollutant distribution, $\mathrm{PM}_{2.5}$ is the most important factor, followed by $\mathrm{O}_{3}$ and $\mathrm{SO}_{2}$. Again, $\mathrm{PM}_{2.5}$ drives the variability of the health indices also using multivariate analysis. 
Table S1. Model evaluation over the European and North American domains (hourly for $\mathrm{O}_{3}, \mathrm{CO}$ and $\mathrm{SO}_{2}$ and daily means for PM 2.5 ). Units are $\%$ for $N M B$ and NMGE, $\mu \mathrm{g} \mathrm{m}^{-3}$ for all species for Europe and $\mathrm{ppb}$ for the gaseous species and $\mu \mathrm{g} \mathrm{m}^{-3}$ for $\mathrm{PM}_{2.5}$ in North America.

\begin{tabular}{|c|c|c|c|c|c|c|c|c|c|c|c|c|c|c|c|c|}
\hline & \multicolumn{4}{|c|}{$\mathrm{O}_{3}$} & \multicolumn{4}{|c|}{$\mathrm{CO}$} & \multicolumn{4}{|c|}{$\mathrm{SO}_{2}$} & \multicolumn{4}{|c|}{$\mathrm{PM}_{2.5}$} \\
\hline Models & $r$ & $N M B$ & NMGE & RMSE & $r$ & $N M B$ & NMGE & RMSE & $r$ & $N M B$ & NMGE & RMSE & $r$ & $N M B$ & NMGE & RMSE \\
\hline \multicolumn{17}{|c|}{ Europe } \\
\hline DE1 & 0.73 & 9.87 & 4.59 & 13.50 & 0.80 & -42.07 & 41.75 & 133.24 & 0.77 & 4.34 & 21.07 & 1.33 & 0.88 & -63.08 & 128.10 & 11.95 \\
\hline DK1 & 0.88 & 6.71 & 2.59 & 9.99 & 0.74 & -41.67 & 43.10 & 135.84 & 0.85 & -47.24 & 56.49 & 1.54 & 0.86 & -45.69 & 56.82 & 9.65 \\
\hline ES1 & 0.79 & -15.16 & 6.59 & 14.21 & 0.59 & -46.27 & 55.42 & 147.82 & 0.78 & -68.13 & 182.02 & 2.15 & 0.23 & -30.84 & 44.68 & 9.66 \\
\hline FI1 & 0.84 & -35.87 & 24.00 & 23.58 & 0.85 & -26.75 & 15.78 & 92.11 & 0.82 & -20.49 & 17.26 & 1.05 & 0.58 & -26.98 & 29.18 & 8.02 \\
\hline FRES1 & 0.78 & -9.65 & 4.79 & 12.51 & 0.82 & -39.19 & 34.10 & 123.37 & 0.74 & -76.81 & 320.13 & 2.44 & 0.87 & -36.16 & 32.25 & 7.88 \\
\hline IT1 & 0.90 & 4.20 & 2.45 & 9.60 & 0.82 & -36.81 & 31.23 & 120.35 & 0.79 & -29.78 & 28.19 & 1.26 & 0.78 & -18.25 & 14.88 & 6.06 \\
\hline IT2 & 0.92 & -14.26 & 4.46 & 11.76 & 0.77 & -43.53 & 45.13 & 136.44 & 0.81 & -54.78 & 87.14 & 1.77 & 0.11 & -48.40 & 87.23 & 11.65 \\
\hline NL1 & 0.92 & -5.06 & 2.01 & 8.30 & 0.69 & -46.09 & 55.74 & 148.51 & 0.80 & -51.92 & 83.39 & 1.79 & 0.76 & -55.55 & 99.64 & 11.56 \\
\hline TR1 & 0.86 & 8.09 & 8.91 & 18.65 & 0.84 & -20.11 & 9.40 & 74.24 & 0.43 & 2.28 & 24.06 & 1.40 & 0.60 & -19.16 & 21.08 & 7.17 \\
\hline UK1 & 0.91 & 7.51 & 2.13 & 9.10 & 0.59 & -41.56 & 44.88 & 138.72 & 0.73 & -12.96 & 16.19 & 1.06 & 0.78 & -40.32 & 44.67 & 8.97 \\
\hline UK2 & 0.83 & -2.75 & 4.17 & 12.10 & 0.64 & -42.63 & 45.23 & 138.00 & 0.72 & 20.46 & 17.82 & 1.31 & 0.77 & -28.28 & 23.59 & 7.15 \\
\hline UK3 & 0.78 & -1.01 & 4.04 & 12.01 & 0.80 & -45.04 & 48.32 & 139.60 & 0.64 & 48.75 & 46.00 & 2.34 & 0.94 & -43.82 & 42.44 & 8.48 \\
\hline MEAN & 0.84 & -3.95 & 5.89 & 12.94 & 0.75 & -39.31 & 39.17 & 127.35 & 0.74 & -23.86 & 74.98 & 1.62 & 0.68 & -38.04 & 52.05 & 9.02 \\
\hline MEDIAN & 0.85 & -1.88 & 4.32 & 12.06 & 0.78 & -41.87 & 43.99 & 136.14 & 0.77 & -25.14 & 37.10 & 1.47 & 0.77 & -38.24 & 43.56 & 8.73 \\
\hline \multicolumn{17}{|c|}{ North America } \\
\hline DE1 & 0.85 & 5.55 & 11.65 & 4.69 & 0.41 & -40.68 & 40.71 & 92.20 & 0.45 & -40.20 & 41.05 & 1.35 & 0.74 & -62.65 & 62.65 & 6.97 \\
\hline DK1 & 0.72 & 21.75 & 23.80 & 10.33 & 0.47 & -7.41 & 18.02 & 47.32 & 0.63 & -42.36 & 43.47 & 1.35 & 0.64 & -14.08 & 22.21 & 2.86 \\
\hline US3 & 0.88 & -1.53 & 11.18 & 4.51 & 0.44 & -3.89 & 19.89 & 51.42 & 0.52 & -12.83 & 23.98 & 0.84 & 0.76 & 17.23 & 23.75 & 3.25 \\
\hline MEAN & 0.82 & 8.59 & 15.54 & 6.51 & 0.44 & -17.33 & 26.21 & 63.65 & 0.53 & -31.80 & 36.17 & 1.18 & 0.71 & -19.83 & 36.21 & 4.36 \\
\hline MEDIAN & 0.85 & 5.55 & 11.65 & 4.69 & 0.44 & -7.41 & 19.89 & 51.42 & 0.52 & -40.20 & 41.05 & 1.35 & 0.74 & -14.08 & 23.75 & 3.25 \\
\hline
\end{tabular}


Table S2. Health impacts as calculated by the individual models over Europe and the United States ( $\times 10^{3}$, except for IM). See Table 2 for the definitions of health impacts. PD stands for premature death (mortality).

\begin{tabular}{|c|c|c|c|c|c|c|c|c|c|c|c|c|c|c|}
\hline Models & CB & RAD & RHA & $\mathrm{CHA}$ & $\mathrm{CHF}$ & $\mathrm{LC}$ & BUC & BUA & COUC & COUA & LRSC & LRSA & PD & IM \\
\hline \multicolumn{15}{|c|}{ Europe } \\
\hline DE1 & 191 & 194776 & 13 & 24 & 19 & 29 & 5694 & 37284 & 19674 & 38380 & 7592 & 13844 & 232 & 213 \\
\hline DK1 & 290 & 296611 & 17 & 37 & 26 & 44 & 8671 & 56776 & 29960 & 58446 & 11562 & 21082 & 336 & 325 \\
\hline FI1 & 411 & 420220 & 25 & 53 & 35 & 63 & 12285 & 80437 & 42445 & 82803 & 16380 & 29868 & 457 & 460 \\
\hline FRES1 & 373 & 381243 & 22 & 48 & 32 & 57 & 11146 & 72976 & 38509 & 75123 & 14861 & 27098 & 419 & 418 \\
\hline IT1 & 507 & 517996 & 30 & 65 & 41 & 78 & 15144 & 99153 & 52322 & 102070 & 20191 & 36818 & 571 & 568 \\
\hline NL1 & 264 & 269418 & 16 & 34 & 24 & 40 & 7876 & 51571 & 27213 & 53088 & 10502 & 19150 & 303 & 295 \\
\hline TR1 & 460 & 470496 & 29 & 59 & 40 & 70 & 13755 & 90061 & 47524 & 92710 & 18340 & 33442 & 538 & 516 \\
\hline UK1 & 343 & 351026 & 23 & 44 & 30 & 53 & 10262 & 67192 & 35456 & 69169 & 13683 & 24950 & 404 & 516 \\
\hline UK2 & 417 & 425950 & 28 & 53 & 35 & 64 & 12453 & 81534 & 43024 & 83932 & 16603 & 30275 & 488 & 467 \\
\hline UK3 & 342 & 349974 & 26 & 44 & 29 & 52 & 10231 & 66991 & 35350 & 68961 & 13642 & 24875 & 416 & 383 \\
\hline MEAN & 360 & 368266 & 23 & 46 & 31 & 55 & 10766 & 70492 & 37198 & 72566 & 14355 & 26175 & 414 & 414 \\
\hline US3 & 204 & 209023 & 13 & 27 & 18 & 31 & 6604 & 40009 & 22819 & 41186 & 8806 & 14856 & 224 & 209 \\
\hline MEAN & 142 & 145337 & 10 & 19 & 13 & 22 & 4566 & 27819 & 15776 & 28637 & 6088 & 10330 & 165 & 143 \\
\hline MEDIAN & 161 & 164681 & 10 & 21 & 15 & 25 & 5148 & 31522 & 17787 & 32449 & 6864 & 11705 & 191 & 161 \\
\hline
\end{tabular}


Table S3. Standardized regression coefficients and coefficient of model determination for the relations between concentration inputs and health impact indices in the EVA system.

\begin{tabular}{|c|c|c|c|c|c|}
\hline Percentile & $\mathrm{SRC}_{\mathrm{O} 3}$ & $\mathrm{SRC}_{\mathrm{PM} 2.5}$ & $\mathrm{SRC}_{\mathrm{SO} 2}$ & $\mathrm{SRC}_{\mathrm{CO}}$ & $\mathrm{R}^{2}$ \\
\hline $1^{\text {st }}$ & -0.88 & 0.37 & -0.37 & 0.32 & 0.84 \\
\hline $5^{\text {th }}$ & -0.15 & 0.76 & 0.38 & -0.06 & 0.96 \\
\hline $10^{\text {th }}$ & -0.17 & 0.67 & 0.25 & 0.12 & 0.89 \\
\hline $25^{\text {th }}$ & -0.06 & 0.61 & 0.13 & 0.30 & 0.76 \\
\hline $50^{\text {th }}$ & 0.12 & 0.74 & -0.02 & 0.24 & 0.76 \\
\hline $75^{\text {th }}$ & 0.27 & 0.81 & -0.20 & 0.08 & 0.81 \\
\hline $90^{\text {th }}$ & 0.38 & 0.76 & -0.34 & 0.04 & 0.82 \\
\hline $95^{\text {th }}$ & 0.45 & 0.72 & -0.40 & 0.02 & 0.83 \\
\hline $99^{\text {th }}$ & 0.56 & 0.69 & -0.45 & -0.01 & 0.89 \\
\hline
\end{tabular}


Table S4. Health impacts as calculated by the individual models over Europe and the United States ( $\times 10^{3}$, except for IM) in response to a $20 \%$ reduction of global anthropogenic emissions (GLO). See Table 2 for the definitions of health impacts.

\begin{tabular}{|c|c|c|c|c|c|c|c|c|c|c|c|c|c|c|}
\hline Models & $\mathrm{CB}$ & RAD & RHA & $\mathrm{CHA}$ & $\mathrm{CHF}$ & $\mathrm{LC}$ & BUC & BUA & COUC & COUA & LRSC & LRSA & $\mathrm{PD}$ & $\mathrm{IM}^{*}$ \\
\hline \multicolumn{15}{|c|}{ Europe } \\
\hline DE1 & 153 & 156353 & 11 & 20 & 16 & 23 & 4571 & 29929 & 15793 & 30809 & 6095 & 11113 & 184 & 171 \\
\hline DK1 & 258 & 263761 & 15 & 33 & 23 & 40 & 7711 & 50488 & 26642 & 51973 & 10281 & 18748 & 297 & 289 \\
\hline FI1 & 345 & 352263 & 21 & 44 & 30 & 53 & 10298 & 67429 & 35581 & 69412 & 13731 & 25038 & 382 & 386 \\
\hline FRES1 & 305 & 312159 & 18 & 39 & 27 & 47 & 9126 & 59753 & 31531 & 61510 & 12168 & 22187 & 342 & 342 \\
\hline IT1 & 414 & 423452 & 24 & 53 & 34 & 63 & 12380 & 81056 & 42772 & 83440 & 16506 & 30098 & 467 & 464 \\
\hline IT2 & 267 & 273062 & 16 & 34 & 23 & 41 & 7983 & 52269 & 27581 & 53806 & 10644 & 19409 & 296 & 299 \\
\hline TR1 & 378 & 386412 & 24 & 48 & 33 & 58 & 11297 & & 39030 & & 15062 & 27465 & 459 & 423 \\
\hline UK1 & 282 & 287915 & 19 & 36 & 25 & 43 & 8417 & 55112 & 29082 & 56733 & 11223 & 20464 & 5370 & 315 \\
\hline UK2 & 333 & 340662 & 22 & 43 & 28 & 51 & 9959 & 65208 & 34409 & 67126 & 13279 & 24213 & 390 & 373 \\
\hline MEAN & 304 & 310671 & 19 & 39 & 27 & 47 & 9082 & 59468 & 31380 & 61217 & 12110 & 22082 & 910 & 340 \\
\hline MEDIAN & 305 & 312159 & 19 & 39 & 27 & 47 & 9126 & 59753 & 31531 & 61510 & 12168 & 22187 & 382 & 342 \\
\hline \multicolumn{15}{|c|}{ The United States } \\
\hline DE1 & 53 & 53735 & 3 & 7 & 4 & 8 & 1679 & 10286 & 5801 & 10588 & 2239 & 3819 & 62 & 52 \\
\hline DK1 & 132 & 135058 & 7 & 17 & 9 & 20 & 4221 & 25852 & 14585 & 26612 & 5628 & 9599 & 153 & 132 \\
\hline US3 & 168 & 171411 & 9 & 22 & 11 & 26 & 5414 & 32809 & 18707 & 33774 & 7219 & 12183 & 176 & 171 \\
\hline MEAN & 117 & 120068 & 6 & 15 & 8 & 18 & 3772 & 22982 & 13031 & 23658 & 5029 & 8534 & 130 & 118 \\
\hline MEDIAN & 132 & 135058 & 7 & 17 & 9 & 20 & 4221 & 25852 & 14585 & 26612 & 5628 & 9599 & 153 & 132 \\
\hline
\end{tabular}


Table S5. Health impacts as calculated by the individual models over Europe and the United States ( $\times 10^{3}$, except for IM) in response to a $20 \%$ reduction of North American anthropogenic emissions (NAM). See Table 2 for the definitions of health impacts.

\begin{tabular}{|c|c|c|c|c|c|c|c|c|c|c|c|c|c|c|}
\hline Models & $\mathrm{CB}$ & RAD & RHA & CHA & $\mathrm{CHF}$ & $\mathrm{LC}$ & BUC & BUA & COUC & COUA & LRSC & LRSA & $\mathrm{PD}$ & $\mathrm{IM}^{*}$ \\
\hline \multicolumn{15}{|c|}{ Europe } \\
\hline DE1 & 191 & 194812 & 13 & 24 & 19 & 29 & 5695 & 37290 & 19677 & 38387 & 7594 & 13847 & 231 & 213 \\
\hline DK1 & 290 & 296847 & 17 & 37 & 26 & 44 & 8678 & 56822 & 29984 & 58493 & 11571 & 21099 & 337 & 325 \\
\hline FI1 & 410 & 419694 & 25 & 53 & 35 & 63 & 12270 & 80336 & 42392 & 82699 & 16360 & 29831 & 457 & 460 \\
\hline FRES1 & 372 & 379831 & 22 & 48 & 32 & 57 & 11104 & 72706 & 38366 & 74844 & 14806 & 26997 & 418 & 416 \\
\hline TR1 & 460 & 469841 & 29 & 59 & 40 & 70 & 13736 & 89936 & 47458 & 92581 & 18314 & 33395 & 536 & 515 \\
\hline UK1 & 342 & 349960 & 23 & 44 & 30 & 52 & 10231 & 66989 & 35349 & 68959 & 13641 & 24874 & 403 & 383 \\
\hline MEAI & 344 & 351831 & 22 & 44 & 30 & 53 & 10286 & 67346 & 35538 & 69327 & 13714 & 25007 & 397 & 385 \\
\hline MEDIAN & 357 & 364896 & 22 & 46 & 31 & 55 & 10668 & 69847 & 36857 & 71902 & 14224 & 25936 & 410 & 400 \\
\hline \multicolumn{15}{|c|}{ The United States } \\
\hline DE1 & 52 & 53382 & 3 & 7 & 4 & 8 & 1667 & 10218 & 5760 & 10518 & 2223 & 3794 & 62 & 52 \\
\hline DK1 & 134 & 137305 & 7 & 17 & 9 & 21 & 4292 & 26282 & 14830 & 27055 & 5723 & 9759 & 158 & 134 \\
\hline US3 & 169 & 172620 & 9 & 22 & 11 & 26 & 5454 & 33041 & 18845 & 34013 & 7273 & 12269 & 178 & 172 \\
\hline MEAN & 118 & 121102 & 6 & 15 & 8 & 18 & 3805 & 23180 & 13145 & 23862 & 5073 & 8607 & 133 & 120 \\
\hline MEDIAN & 134 & 137305 & 7 & 17 & 9 & 21 & 4292 & 26282 & 14830 & 27055 & 5723 & 9759 & 158 & 134 \\
\hline
\end{tabular}


Table S6. Health impacts as calculated by the individual models over Europe and the United States ( $\times 10^{3}$, except for IM) in response to a $20 \%$ reduction of European (EUR) and East Asian (EAS) anthropogenic emissions. See Table 2 for the definitions of health impacts.

\begin{tabular}{|c|c|c|c|c|c|c|c|c|c|c|c|c|c|c|}
\hline Models & $\mathrm{CB}$ & RAD & RHA & $\mathrm{CHA}$ & $\mathrm{CHF}$ & $\mathrm{LC}$ & BUC & BUA & COUC & COUA & LRSC & LRSA & $\mathrm{PD}$ & $\mathrm{IM}^{*}$ \\
\hline \multicolumn{15}{|c|}{ Europe } \\
\hline DE1 & 154 & 157444 & 11 & 20 & 16 & 24 & 4603 & 30138 & 15903 & 31024 & 6137 & 11191 & 187 & 173 \\
\hline DK1 & 270 & 275740 & 16 & 35 & 24 & 41 & 8061 & 52781 & 27852 & 54333 & 10748 & 19599 & 312 & 302 \\
\hline FI1 & 346 & 353923 & 21 & 44 & 30 & 53 & 10347 & 67747 & 35749 & 69740 & 13796 & 25156 & 384 & 388 \\
\hline FRES1 & 311 & 318365 & 18 & 40 & 28 & 48 & 9307 & 60941 & 32157 & 62733 & 12410 & 22629 & 350 & 349 \\
\hline IT1 & 430 & 440061 & 25 & 55 & 35 & 66 & 12865 & 84235 & 44450 & 86713 & 17154 & 31278 & 487 & 482 \\
\hline UK1 & 291 & 297212 & 19 & 37 & 26 & 45 & 8689 & 56891 & 30021 & 58565 & 11585 & 21125 & 343 & 326 \\
\hline $\mathrm{MEAI}$ & 300 & 307124 & 18 & 39 & 27 & 46 & & 58789 & 31022 & & & & 344 & 336 \\
\hline MEDIAN & 301 & 307788 & 19 & 39 & 27 & 46 & 8998 & 58916 & 31089 & 60649 & 11998 & 21877 & 347 & 337 \\
\hline \multicolumn{15}{|c|}{ The United States } \\
\hline DE1 & 61 & 62470 & 3 & 8 & 4 & 9 & 1951 & 11958 & 6740 & 12309 & 2601 & 4440 & 74 & 61 \\
\hline DK1 & 160 & 163776 & 9 & 21 & 11 & 25 & 5119 & 31349 & 17687 & 32271 & 6826 & 11641 & 180 & 160 \\
\hline US3 & 204 & 208377 & 11 & 27 & 13 & 31 & 6583 & 39885 & 22746 & 41058 & 8778 & 14810 & 214 & 208 \\
\hline MEAN & 142 & 144875 & 8 & 18 & 9 & 22 & 4551 & 27730 & 15724 & 28546 & 6068 & 10297 & 156 & 143 \\
\hline MEDIAN & 160 & 163776 & 9 & 21 & 11 & 25 & 5119 & 31349 & 17687 & 32271 & 6826 & 11641 & 180 & 160 \\
\hline
\end{tabular}



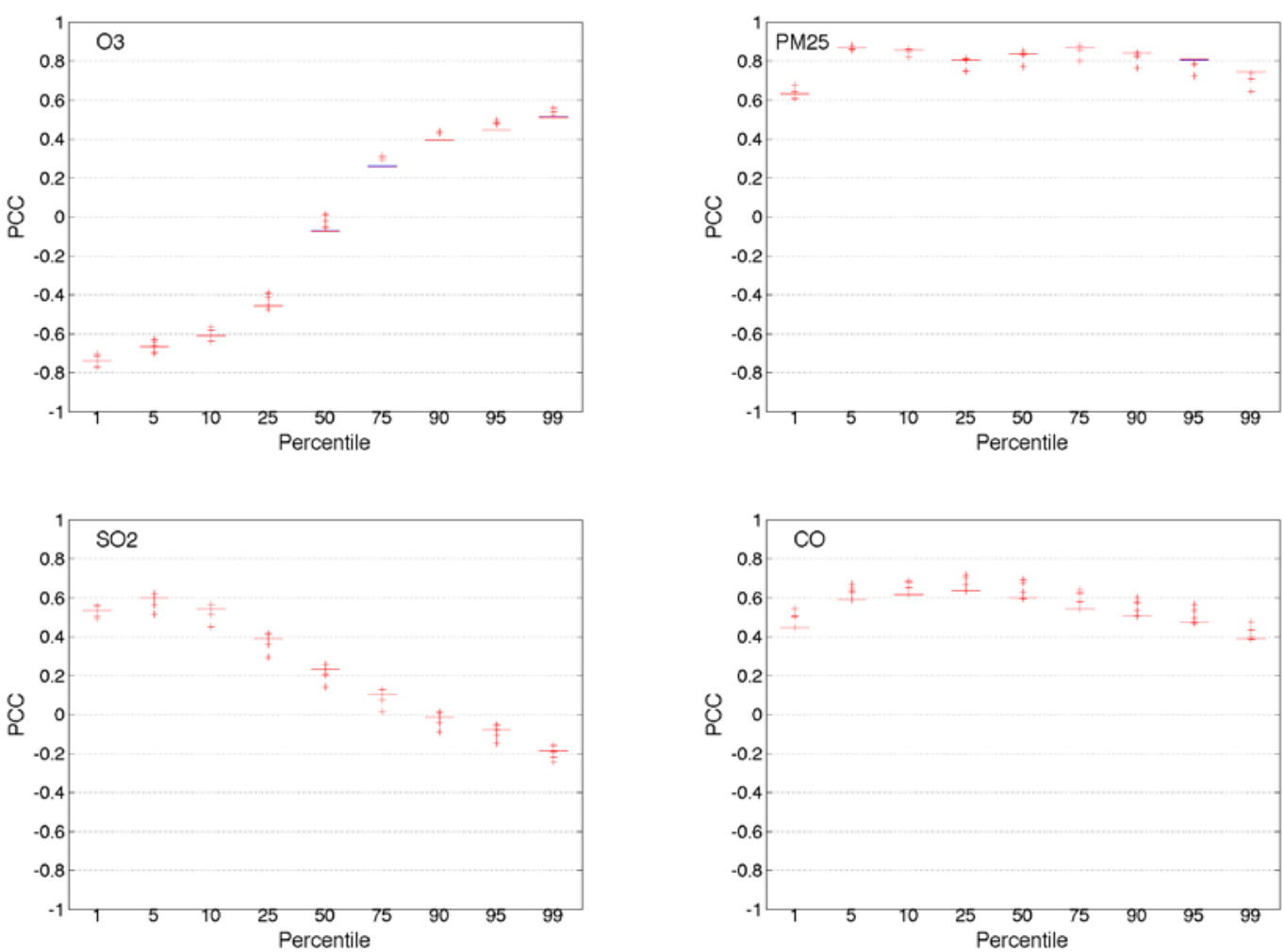

Fig. S1. The Pearson Correlation Coefficient (PCC) between the simulated pollutant levels at 9 discrete percentiles (1, 5, 10, 25, 50, 75, 90, 95, and 99) and health impacts. 

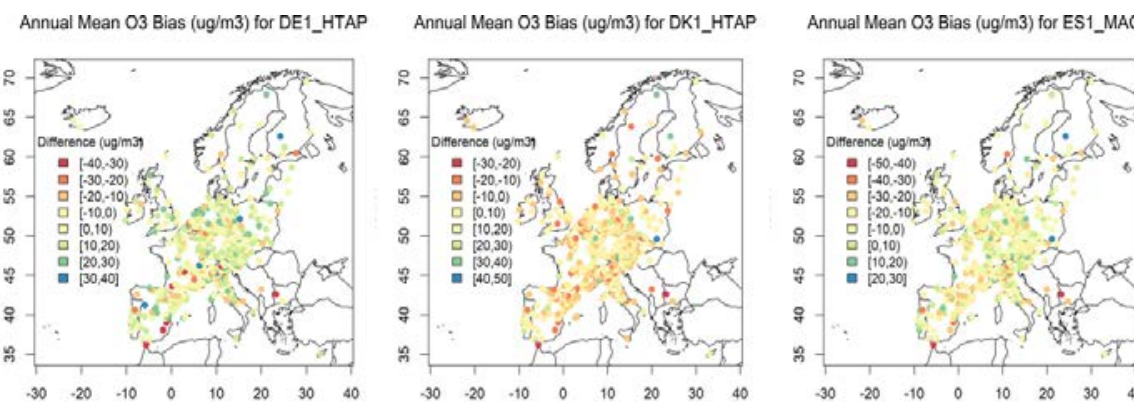

Annual Mean O3 Bias (ug/m3) for Fl1_MACC

Longtude
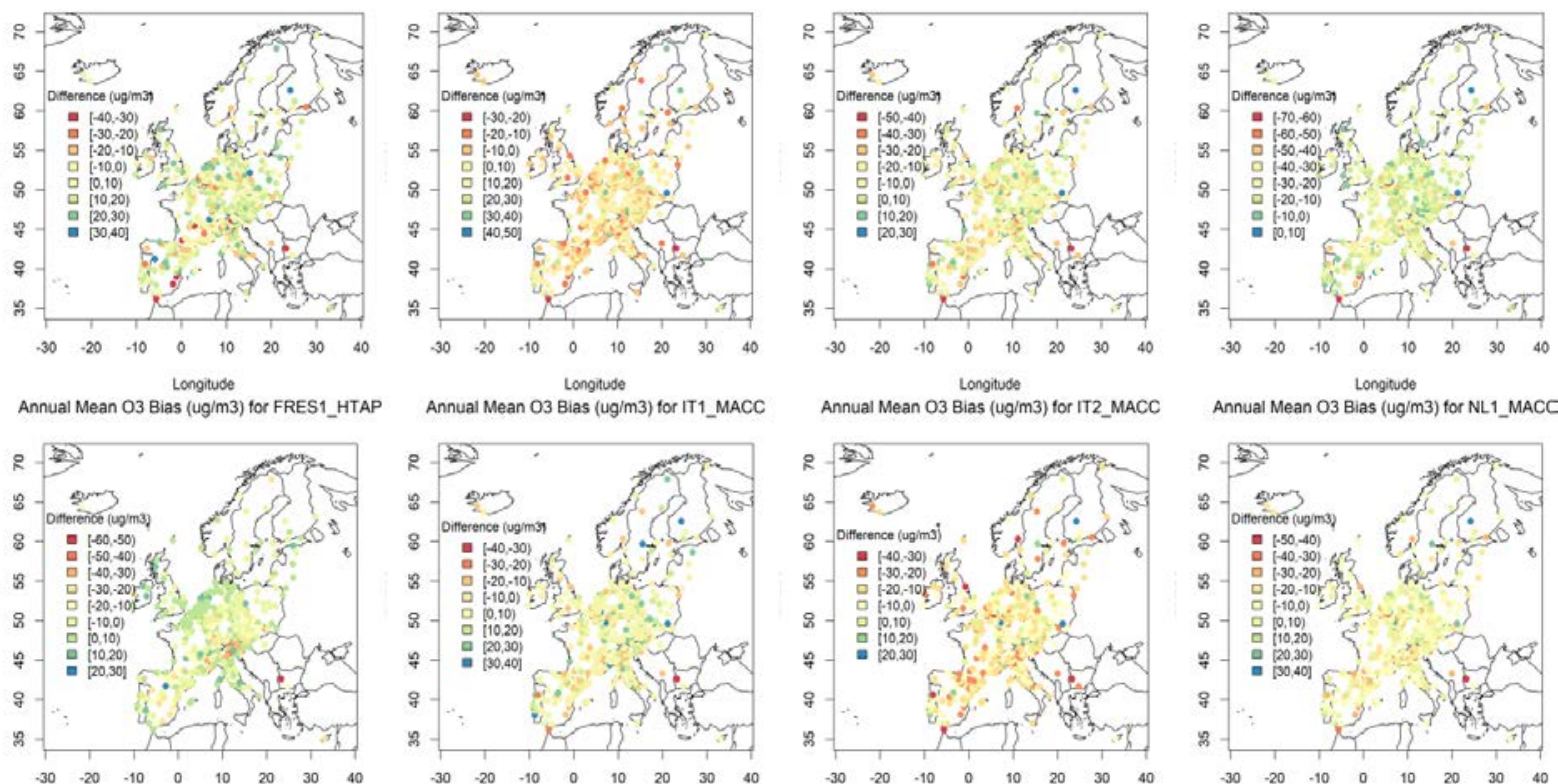

Longtude
Annual Mean 03 Bias (ug/m3) for NL1_MACC

Lononuse
Annual Mean 03 Bias (ug/m3) for TR1 MACC
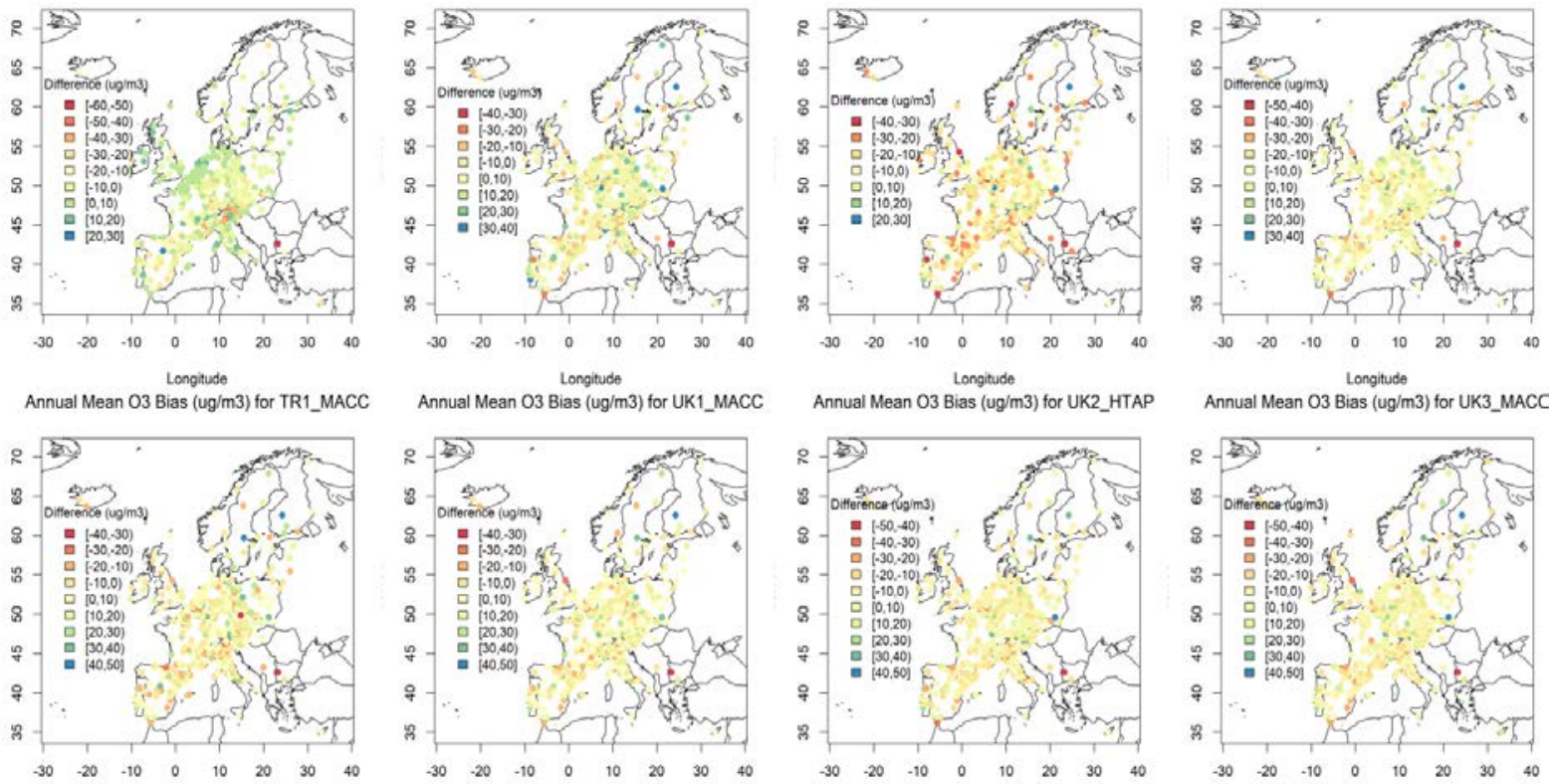

Fig. S2. Geographical distribution of bias (in units of $\mu \mathrm{gm}^{-3}$ ) of simulated $\mathrm{O}_{3}$ over Europe by individual models. 

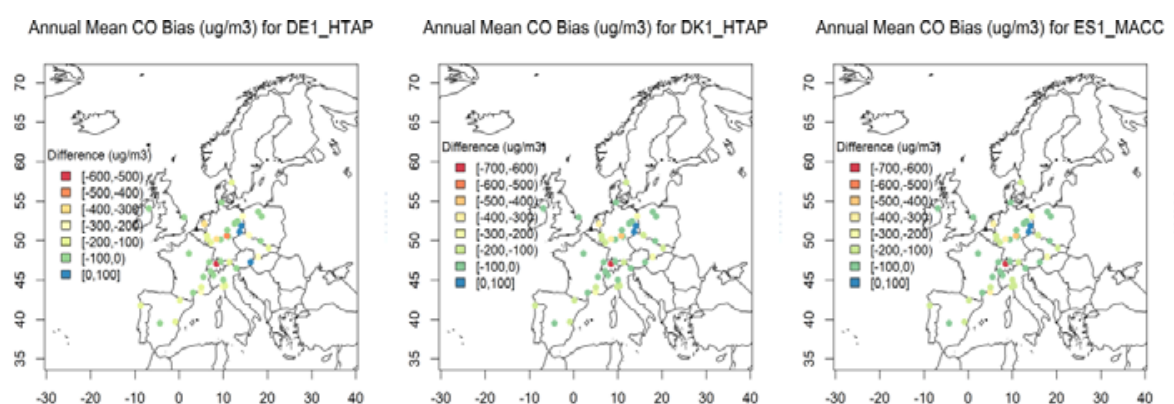

Annual Mean CO Bias (ug/m3) for Fl1_MACC

Longhtude
Anval
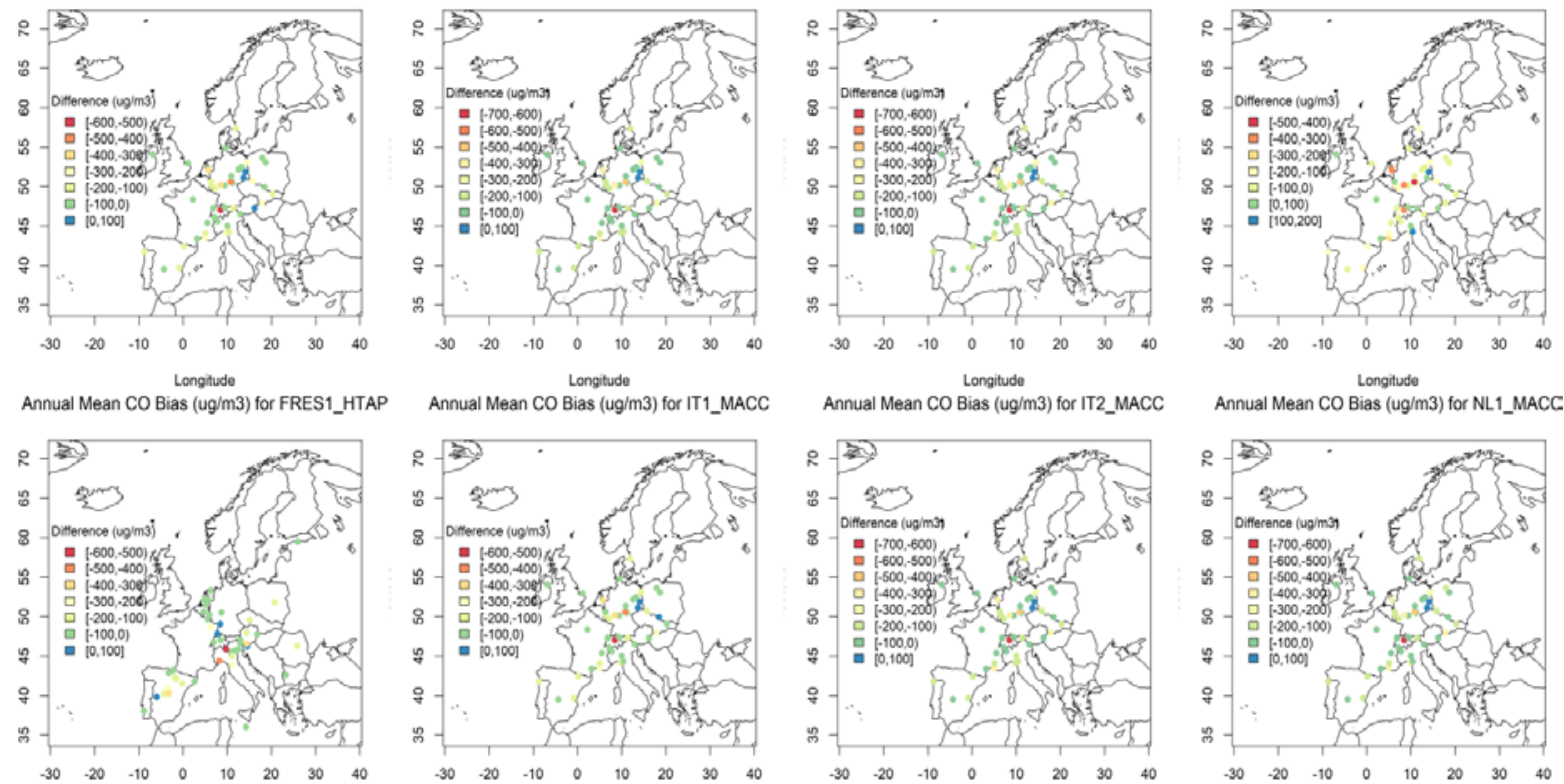

Longtide
Annual Mean $\mathrm{CO}$ Bias (ug/m3) for TR1 MACC
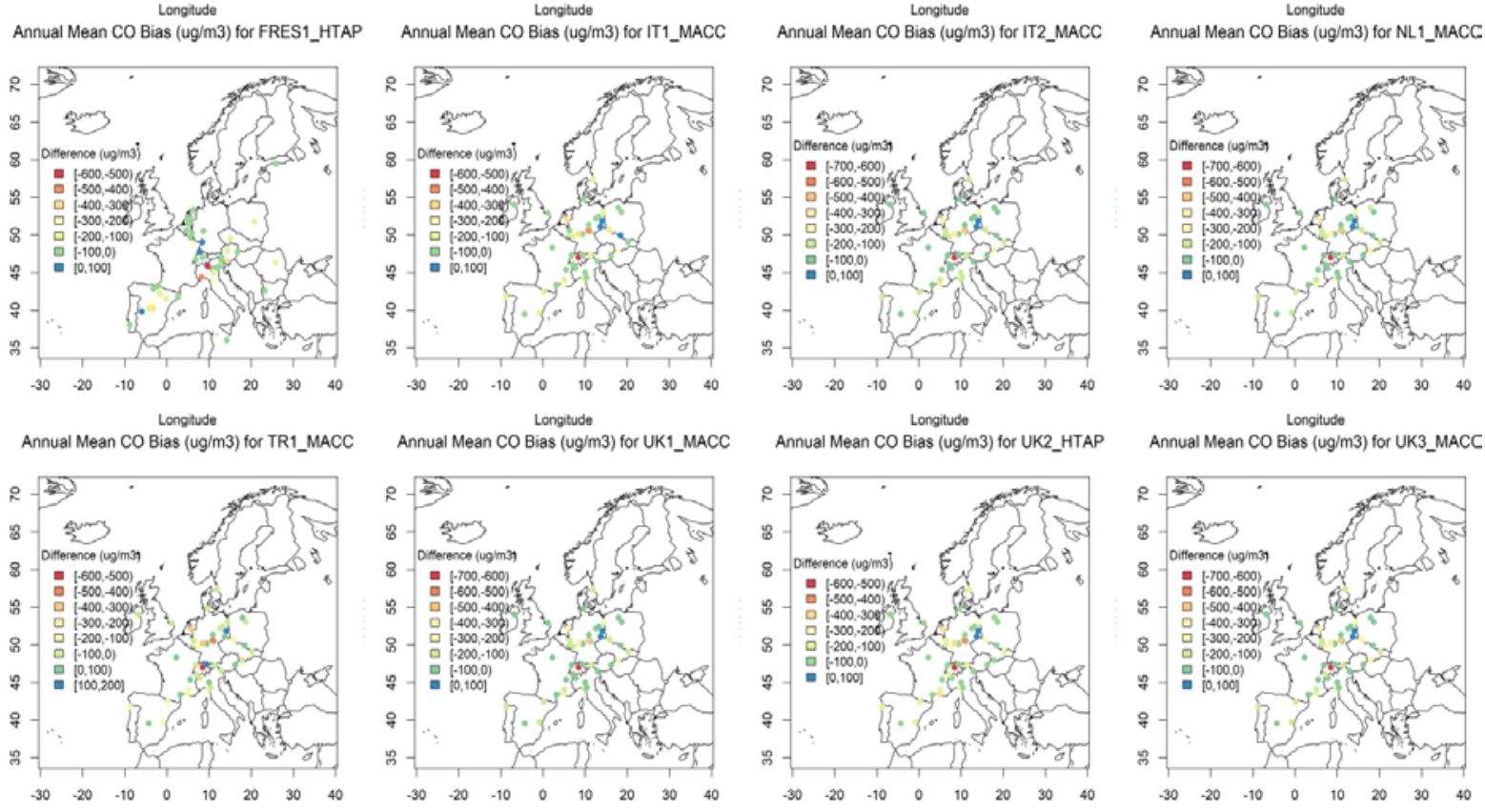

Annual Mean CO Bias (ug/m3) for UK2_HTAP
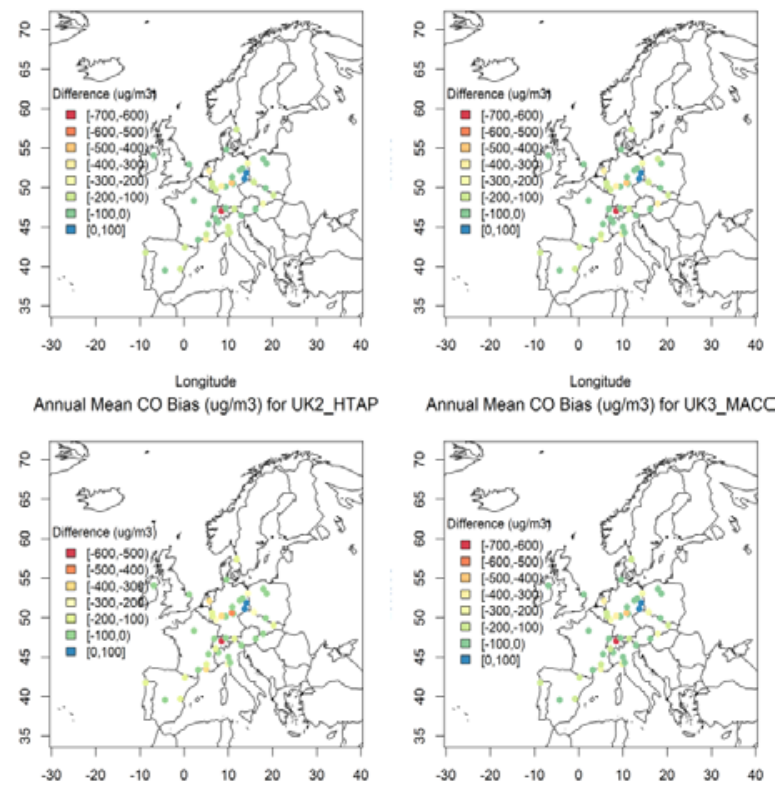

Fig. S3. Geographical distribution of bias (in units of $\mu \mathrm{gm}^{-3}$ ) of simulated CO over Europe by individual models. 

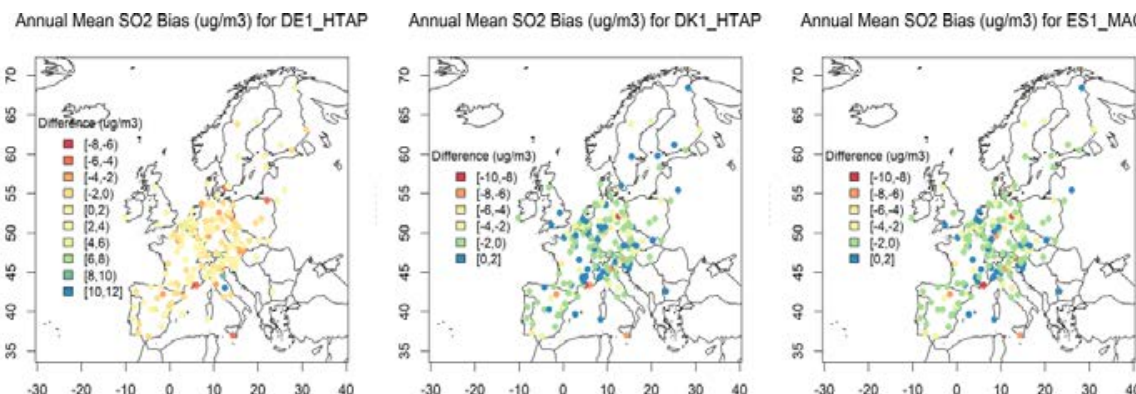

Annual Mean SO2 Bias (ug/m3) for Fl1_MACC

A
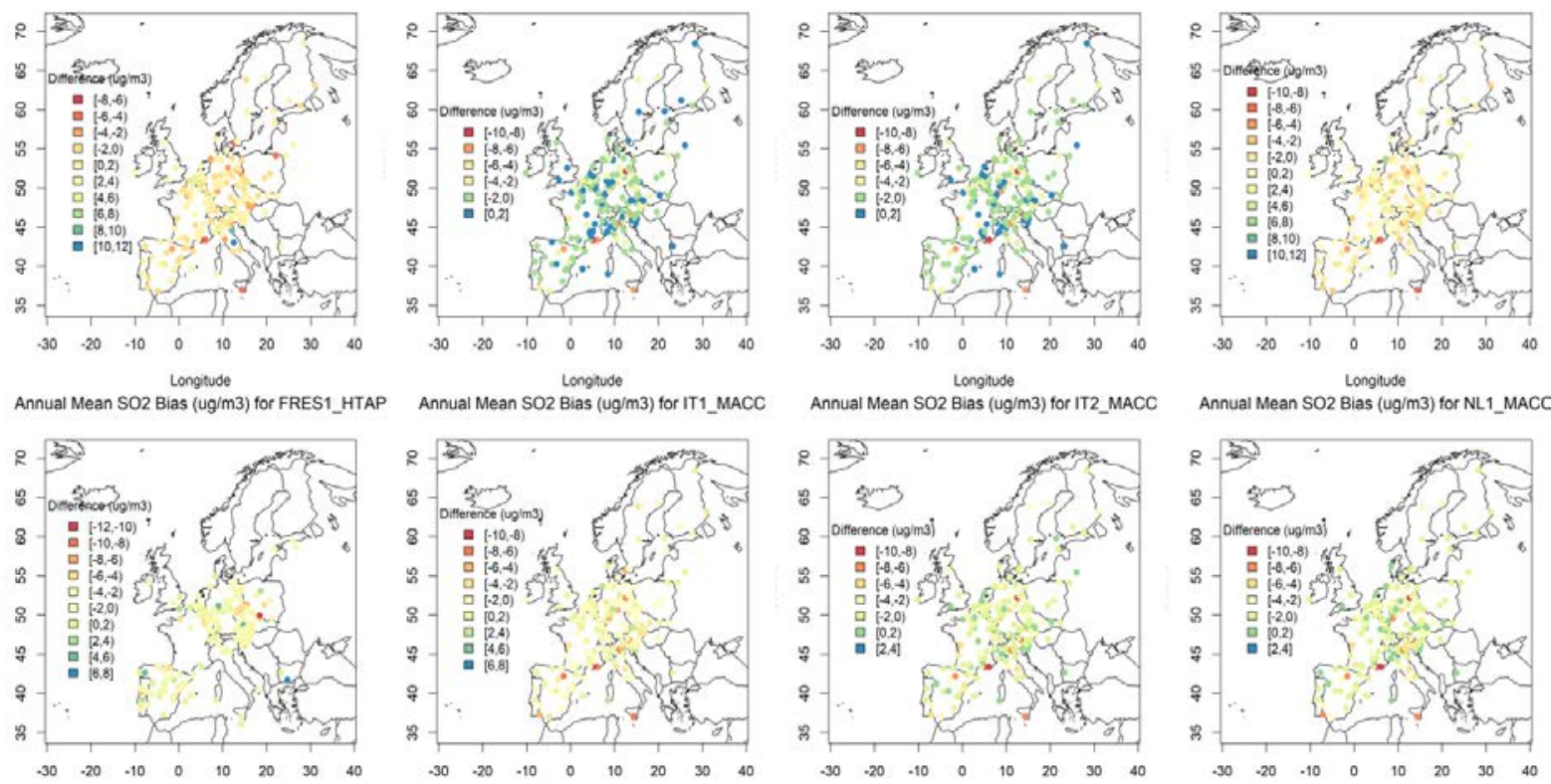

nual Mean SO2 Bias (ug/m3) for TR1_MACC
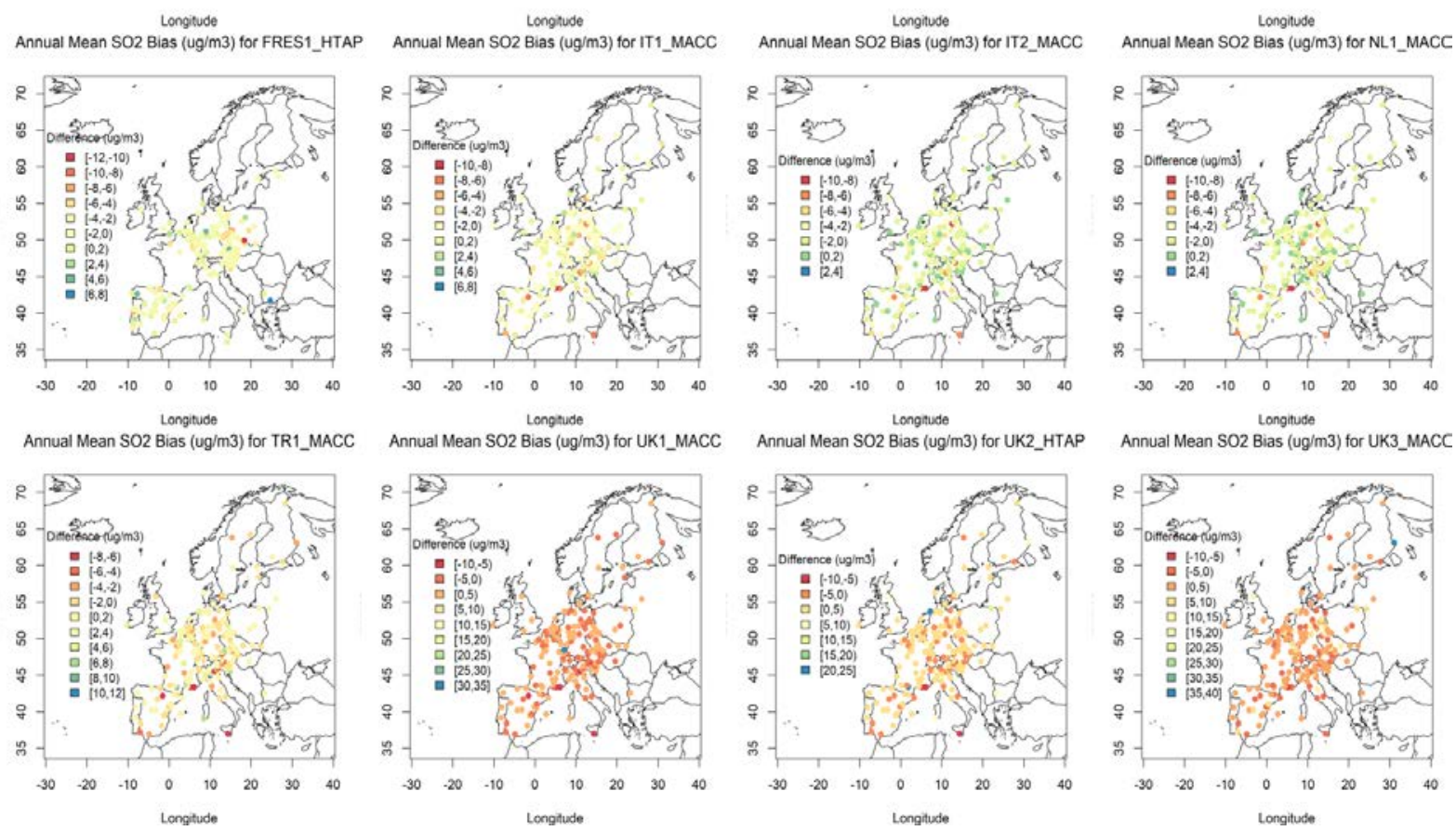

Fig. S4. Geographical distribution of bias (in units of $\mu \mathrm{gm}^{-3}$ ) of simulated $\mathrm{SO}_{2}$ over Europe by individual models. 

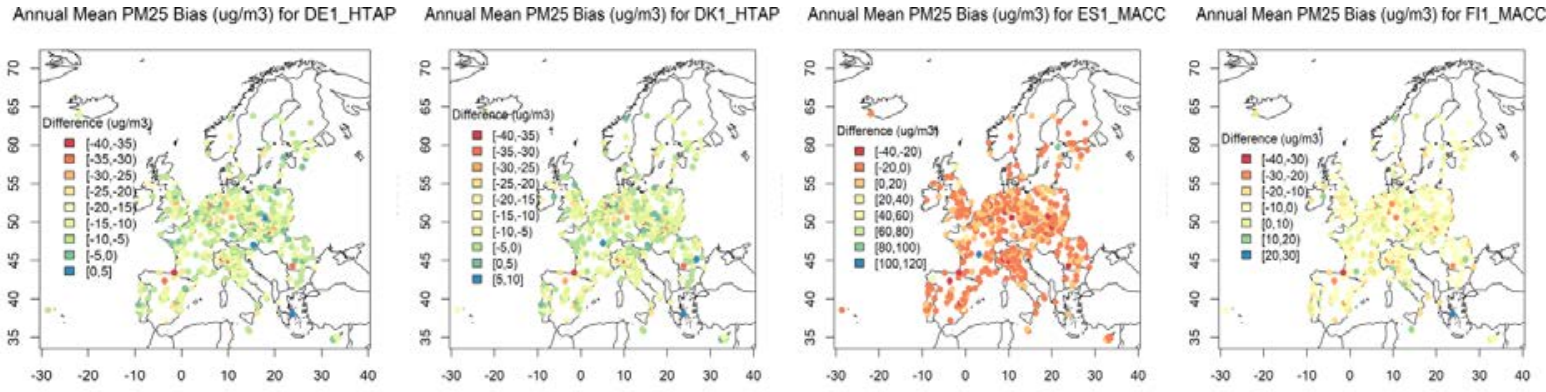

Annual Mean PM25 Bias (ug/m3) for FRES1_HTAP
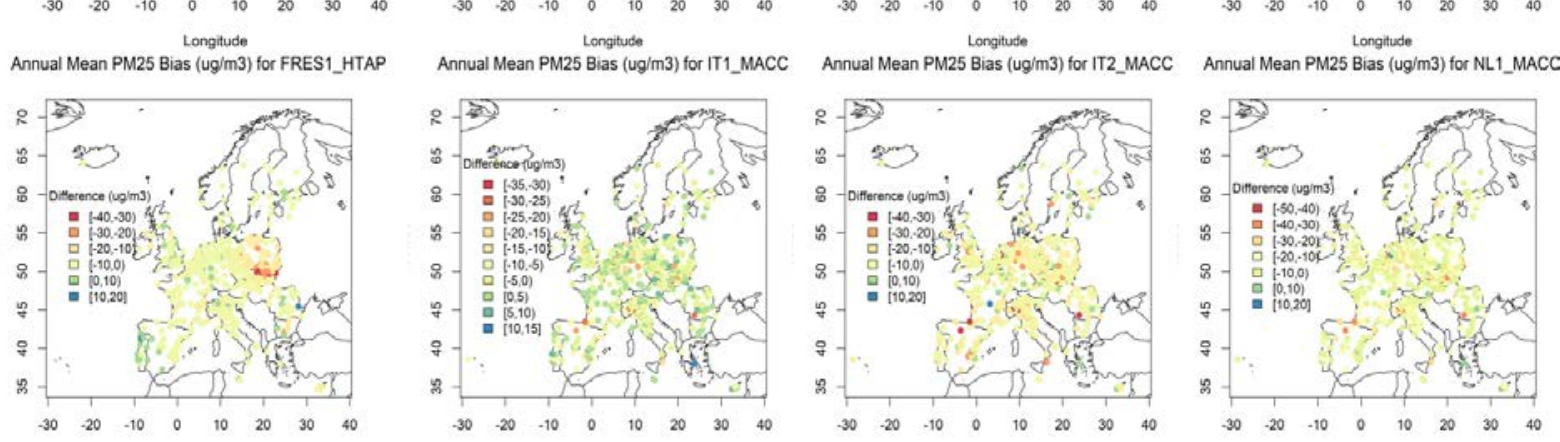

Annual Mean PM25 Bias (ugim3) for TR1_MACC
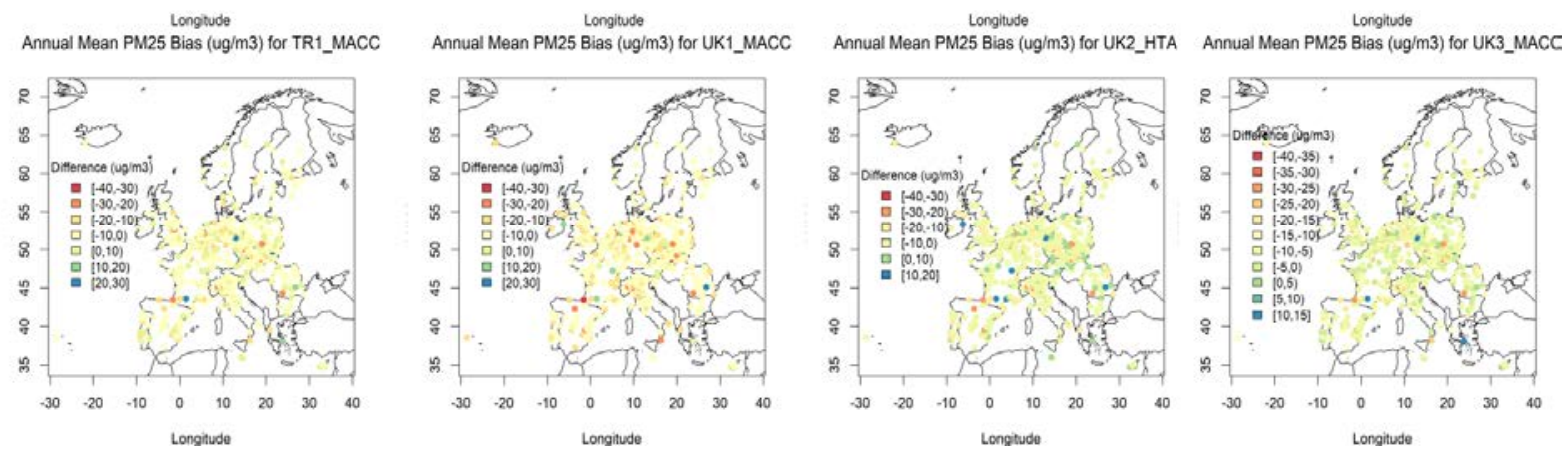

Fig. S5. Geographical distribution of bias (in units of $\mu \mathrm{gm}^{-3}$ ) of simulated $\mathrm{PM}_{2.5}$ over Europe by individual models. 
Annual Mean O3 Bias (ppb) for DE1_HTAP

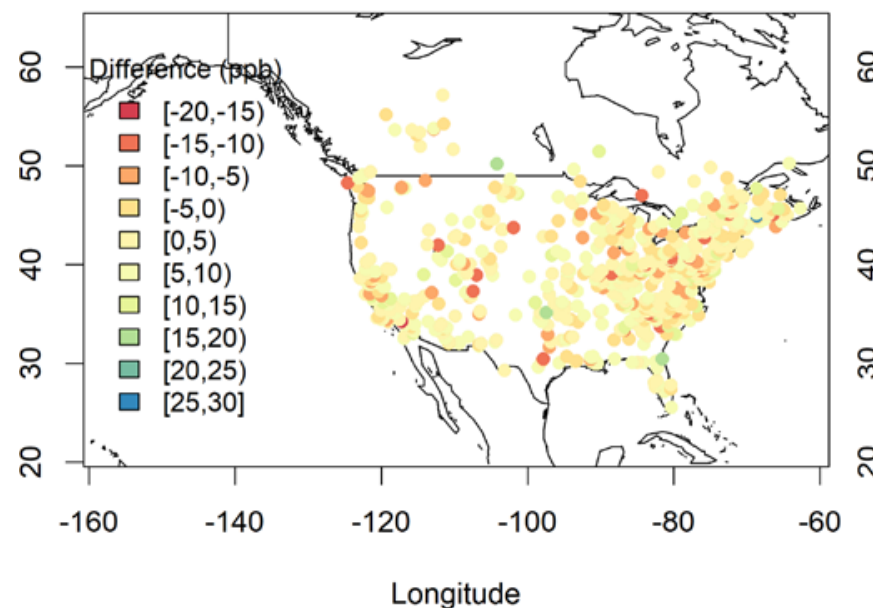

Annual Mean O3 Bias (ppb) for DK1_HTAP

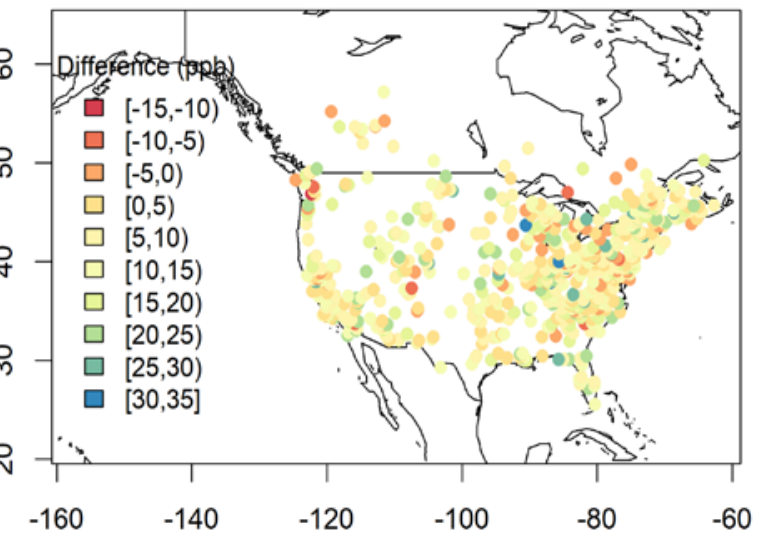

Longitude
Annual Mean O3 Bias (ppb) for US3_SMOKE

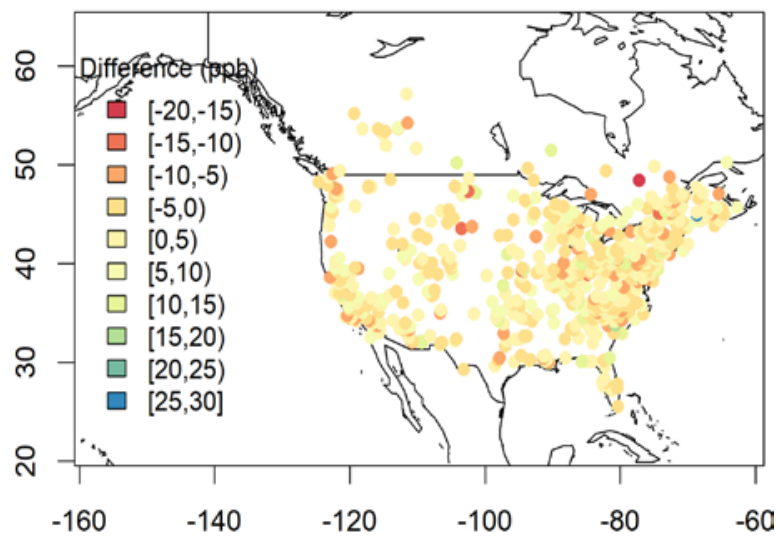

Longitude

Fig. S6. Geographical distribution of bias (in units of $\mathrm{ppb}$ ) of simulated $\mathrm{O}_{3}$ over North America by individual models. 
Annual Mean CO Bias (ppb) for DE1_HTAP

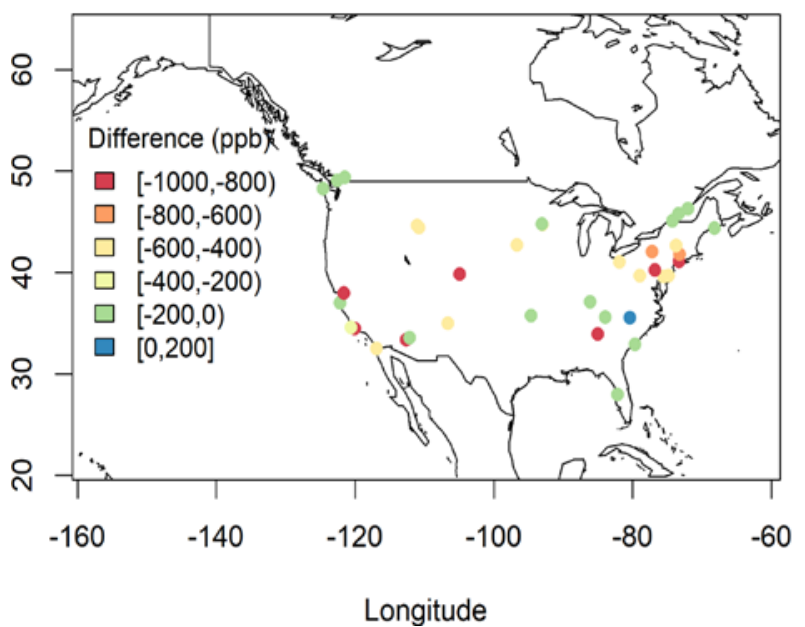

Annual Mean CO Bias (ppb) for DK1_HTAP

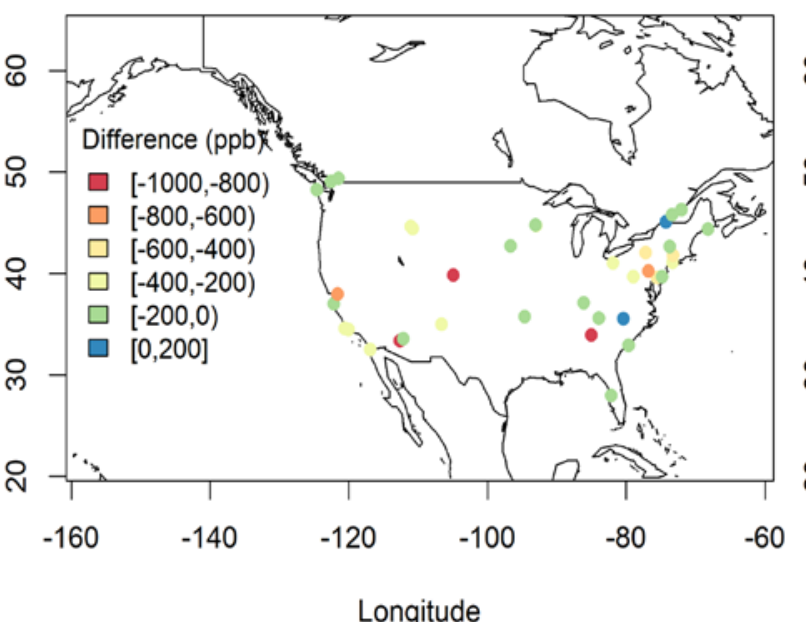

Annual Mean CO Bias (ppb) for US3_SMOKE

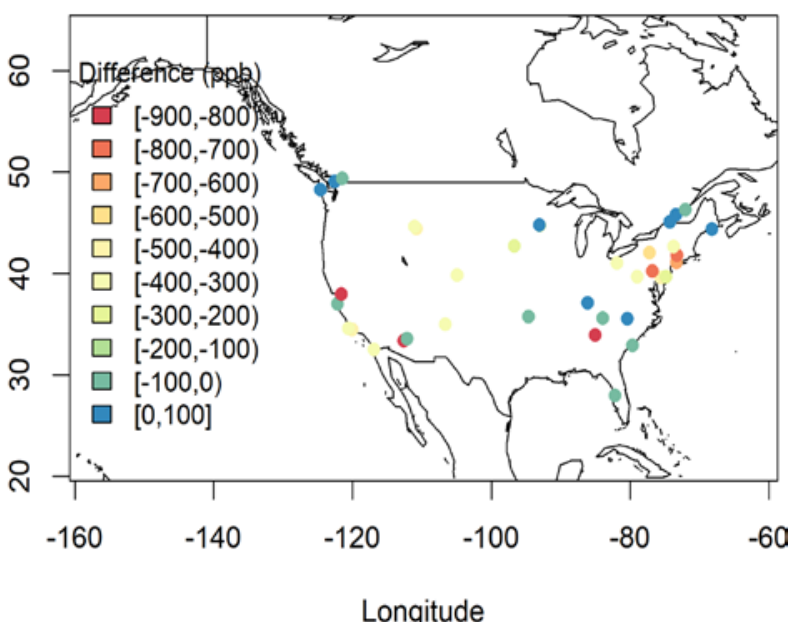

Fig. S7. Geographical distribution of bias (in units of ppb) of simulated CO over North America by individual models. 
Annual Mean SO2 Bias (ppb) for DE1_HTAP

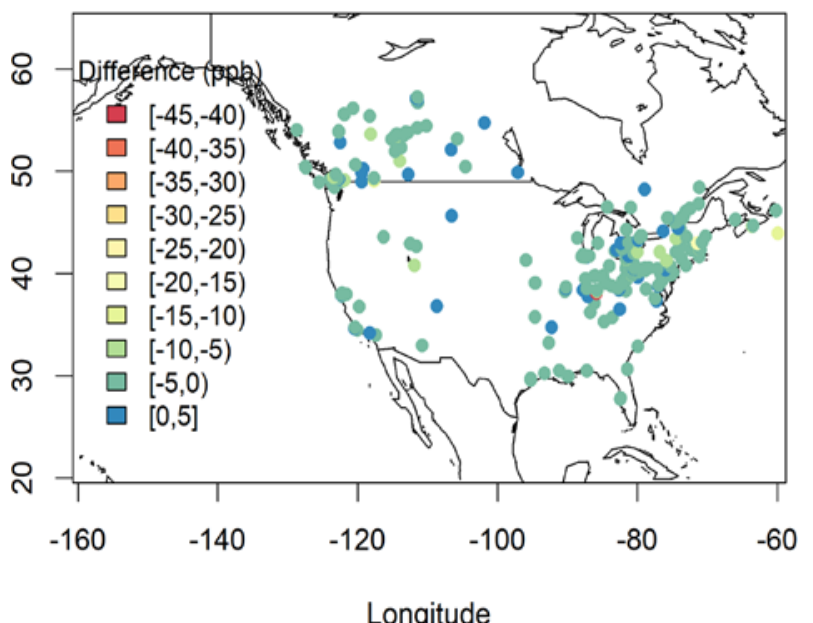

Annual Mean SO2 Bias (ppb) for DK1_HTAP

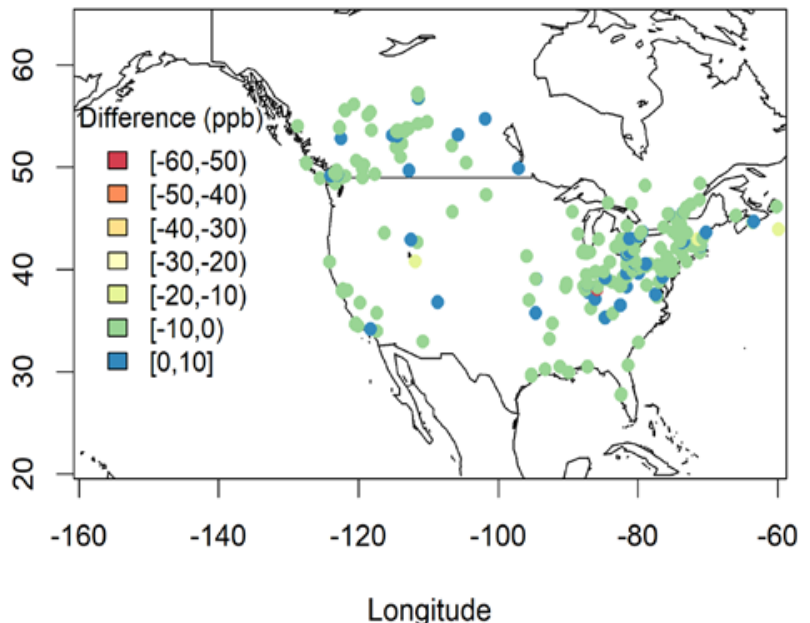

2010 Annual MM MEAN SO2 Bias (ppb)

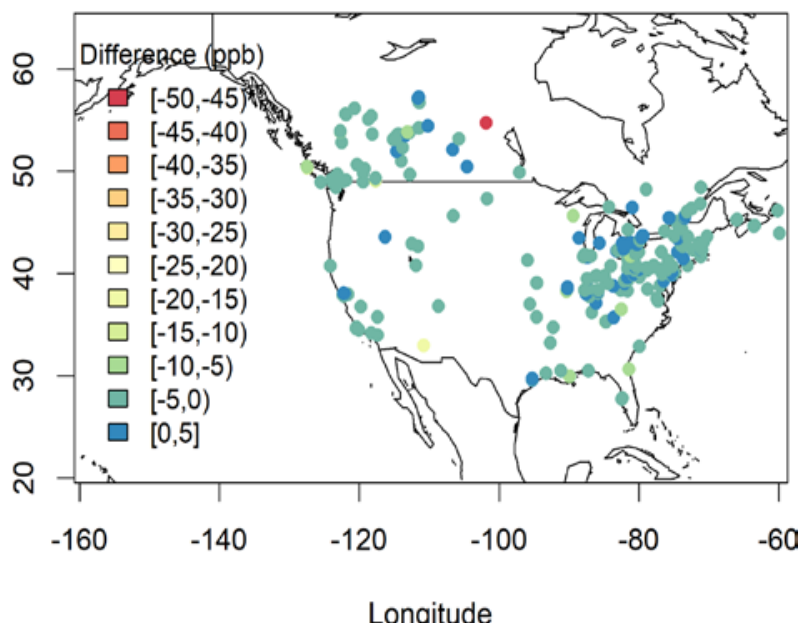

Fig. S8. Geographical distribution of bias (in units of ppb) of simulated $\mathrm{SO}_{2}$ over North America by individual models. 

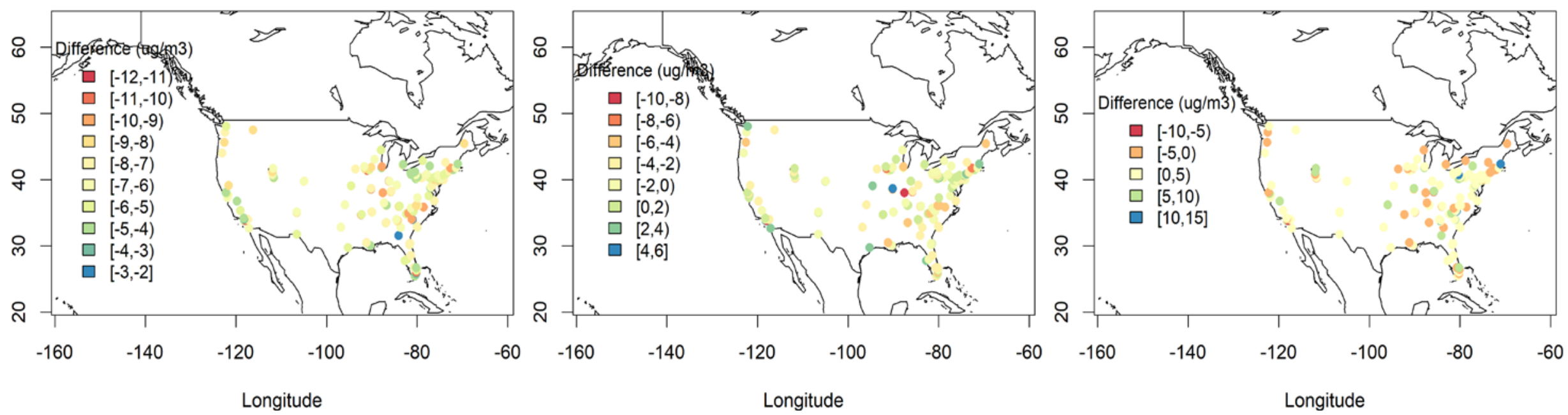

Fig. S9. Geographical distribution of bias (in units of $\mathrm{ppb}$ ) of simulated $\mathrm{PM}_{2.5}$ over North America by individual models. 


\section{REFERENCES}

Ackermann, I. J., Hass, H., Memmsheimer, M., Ebel, A., Binkowski, F. S., and Shankar, U.: Modal aerosol dynamics model for Europe: development and first applications, Atmos. Environ., 32, 2981-2999, doi:10.1016/S1352-2310(98)00006-5, 1998.

Ahmadov, R., McKeen, S. A., Robinson, A., Bahreini, R., Middlebrook, A., de Gouw, J., Meagher, J., Hsie, E., Edgerton, E., Shaw, S., and Trainer, M.: A volatility basis set model for summertime secondary organic aerosols over the eastern United States in 2006, J. Geophys. Res., 117, D06301, doi:10.1029/2011JD016831, 2012.

Appel, K. W., Pouliot, G. A., Simon, H., Sarwar, G., Pye, H. O. T., Napelenok, S. L., Akhtar, F., and Roselle, S. J.: Evaluation of dust and trace metal estimates from the Community Multiscale Air Quality (CMAQ) model version 5.0, Geosci. Model Dev., 6, 883-899, doi:10.5194/gmd-6-883-2013, 2013.

Banzhaf, S., M. Schaap, A. Kerschbaumer, E. Reimer, R. Stern, E. van der Swaluw, and Builtjes, P.: Implementation and evaluation of pH-dependent cloud chemistry and wet deposition in the chemical transport model REM-Calgrid, Atmos. Environ., 49, 378-390, doi:10.1016/j.atmosenv.2011.10.069, 2012.

Beltman, J. B., Hendriks, C., Tum, M., and Schaap, M.: The impact of large scale biomass production on ozone air pollution in Europe, Atmos. Environ., 71, 352-363, doi:10.1016/j.atmosenv.2013.02.019, 2013.

Bergström, R., Denier van der Gon, H. A. C., Prévôt, A. S. H., Yttri, K. E., and Simpson, D.: Modelling of organic aerosols over Europe (2002-2007) using a volatility basis set (VBS) framework: application of different assumptions regarding the formation of secondary organic aerosol, Atmos. Chem. Phys., 12, 8499-8527, doi:10.5194/acp-12-8499-2012, 2012.

Bieser, J., Aulinger, A., Matthias, V., Quante, M., and Builtjes, P.: SMOKE for Europe adaptation, modification and evaluation of a comprehensive emission model for Europe, Geosci. Model Dev., 4, 47-68, doi:10.5194/gmd-4-47-2011, 2011a.

Bieser, J., Aulinger, A., Matthias, V., Quante, M., and Denier van der Gon, H. A. C.: Vertical emission profiles for Europe based on plume rise calculations, Environ. Pollut., 159, 29352946, doi:10.1016/j.envpol.2011.04.030, 2011b.

Brandt, J., Silver, J. D., Frohn, L. M., Geels, C., Gross, A., Hansen, A. B., Hansen, K. M., Hedegaard, G. B., Skjøth, C. A., Villadsen, H., Zare, A., and Christensen, J. H.: An integrated model study for Europe and North America using the Danish Eulerian Hemispheric Model with focus on intercontinental transport, Atmos. Environ., 53, 156-176, 2012.

Byun, D. W. and Schere, K.: Review of the governing equations, computational algorithms, and other components of the Models- 3 community Multiscale Air Quality (CMAQ) modeling system, Appl. Mech. Rev., 59, 51-77, 2006. 
Damski, J., Thölix, L., Backman, L., Taalas, P., and Kulmala, M.: FinROSE: middle atmospheric chemistry transport model, Boreal Environ. Res. 12, 535-550, 2007.

de Leeuw, G., Neele, F. P., Hill, M., Smith, M. H., and Vignati, E.: Production of sea spray aerosol in the surf zone, J. Geophys. Res., 105, e29409, doi:10.1029/2000JD900549, 2000.

Doms, G.: A Description of the Nonhydrostatic Regional COSMO model, Part I: Dynamics and Numerics, Tech. rep., Deutscher Wetterdienst, available at: http://www.cosmomodel.org/content/model/documentation/core/cosmoDyncsNumcs.pdf.

Donahue, N. M., Robinson, A. L., Stanier, C. O., and Pandis, S. N.: Coupled partitioning, dilution, and chemical aging of semivolatile organics, Environ. Sci. Technol., 40.8, 6352643, 2006.

Emberson, L. D., Ashmore, M. R., Simpson, D., Tuovinen, J.-P., and Cambridge, H. M.: Towards a model of ozone deposition and stomatal uptake over Europe. EMEP/MSC-W 6/2000, Norwegian Meteorological Institute, Oslo, Norway, 57 pp., 2000a.

Emberson, L. D., Ashmore, M. R., Simpson, D., Tuovinen, J.-P., and Cambridge, H. M.: Modelling stomatal ozone flux across Europe, Water Air Soil Pollut., 109, 403-413, 2000b.

Fast, J. D., Gustafson Jr., W. I., Easter, R. C., Zaveri, R. A., Barnard, J. C., Chapman, E. G., Grell, G. A., and Peckham, S. E.: Evolution of ozone, particulates, and aerosol direct radiative forcing in the vicinity of Houston using a fully coupled meteorology-chemistryaerosol model, J. Geophys. Res., 111, D21305, doi:10.1029/2005JD006721, 2006.

Foley, K. M., Roselle, S. J., Appel, K. W., Bhave, P. V., Pleim, J. E., Otte, T. L., Mathur, R., Sarwar, G., Young, J. O., Gilliam, R. C., Nolte, C. G., Kelly, J. T., Gilliland, A. B., and Bash, J. O.: Incremental testing of the Community Multiscale Air Quality (CMAQ) modeling system version 4.7, Geosci. Model Dev., 3, 205-226, doi:10.5194/gmd-3-205-2010, 2010.

Fountoukis, C. and Nenes, A.: ISORROPIA II: a computationally efficient thermodynamic equilibrium model for KC-Ca2C-Mg2C-NHC4 -NaC-SO2 $\square 4-\mathrm{NO} \square 3-\mathrm{Cl} \square-\mathrm{H} 2 \mathrm{O}$ aerosols, Atmos. Chem. Phys., 7, 4639-4659, doi:10.5194/acp-7-4639-2007, 2007.

Gantt, B., Kelly, J. T., and Bash, J. O.: Updating sea spray aerosol emissions in the Community Multiscale Air Quality (CMAQ) model version 5.0.2, Geosci. Model Dev., 8, 3733-3746, doi:10.5194/gmd-8-3733-2015, 2015.

Geyer, B.: High-resolution atmospheric reconstruction for Europe 1948-2012: coastDat2, Earth Syst. Sci. Data, 6, 147-164, doi:10.5194/essd-6-147-2014, 2014.

Gilliam, R. C., Godowitch, J. M., and Rao, S. T.: Improving the horizontal transport in the lower troposphere with four dimensional data assimilation, Atmos. Environ., 53, 186-201, doi:10.1016/j.atmosenv.2011.10.064, 2012. 
Ginoux, P., Chin, M., Tegen, I., Prospero, J. M., Holben, B., Dubovik, O., and Lin, S. J.: Sources and distributions of dust aerosols simulated with the GOCART model, J. Geophys. Res., 106, 20255-20273, 2001.

Gong, S. L.: A parameterization of sea-salt aerosol source function for sub- and super-micron particles, Global Biogeochem. Cy., 17, 1097-1104, 2003.

Grell, G. A. and Devenyi, D.: A generalized approach to parameterizing convection combining ensemble and data assimilation techniques, Geophys. Res. Lett., 29, 1693, doi:10.1029/2002GL015311, 2002.

Grell, G. A. and Freitas, S. R.: A scale and aerosol aware stochastic convective parameterization for weather and air quality modeling, Atmos. Chem. Phys., 14, 5233-5250, doi:10.5194/acp-14-5233-2014, 2014.

Guenther, A., Karl, T., Harley, P., Wiedinmyer, C., Palmer, P. I., and Geron, C.: Estimates of global terrestrial isoprene emissions using MEGAN (Model of Emissions of Gases and Aerosols from Nature), Atmos. Chem. Phys., 6, 3181-3210, doi:10.5194/acp-6-3181-2006, 2006.

Guenther, A. B., Jiang, X., Heald, C. L., Sakulyanontvittaya, T., Duhl, T., Emmons, L. K., andWang, X.: The Model of Emissions of Gases and Aerosols from Nature version 2.1 (MEGAN2.1): an extended and updated framework for modeling biogenic emissions, Geosci. Model Dev., 5, 1471-1492, doi:10.5194/gmd-5-1471-2012, 2012.

Hogrefe, C., Pouliot, G., Wong, D., Torian, A., Roselle, S., Pleim, J., and Mathur, R.: Annual application and evaluation of the online coupled WRF-CMAQ system over North America under AQMEII phase 2, Atmos. Environ., 115, 683-694, 2015.

Hong, S.-Y., Noh, Y., and Dudhia, J.: A new vertical diffusion package with explicit treatment of entrainment processes, Mon. Weather Rev., 134, 2318-2341, 2006.

Kalnay, E., Kanamitsu, M., Kistler, R., Collins, W., Deaven, D., Gandin, L., Iredell, M., Saha, S., White, G., Woollen, J.,Zhu, Y., Chelliah, M., Ebisuzaki, W., Higgins, W., Janowiak, J., Mo, K. C., Ropelewski, C., Wang, J., Leetmaa, A.,Reynolds, R., Jenne, R., and Joseph, D.: The NCEP/NCAR 40-year reanalysis project, B. Am. Meteorol. Soc., 77, 437471, 1996.

Kim, S. W., Heckel, A., Frost, G. J., Richter, A., Gleason, J., Burrows, J. P., McKeen, S., Hsie, E. Y., Granier, C., and Trainer, M.: NO2 columns in the western United States observed from space and simulated by a regional chemistry model and their implications for NOx emissions, J. Geophys. Res.-Atmos., 114, D11301, doi:10.1029/2008jd011343, 2009.

Lattuati M.: Impact des emissions européennes sur le bilan d'ozone troposphérique à l'interface de l'Europe et de l'Atlantique Nord: apport de la modélisation lagrangienne et des mesures en altitude, PhD Thesis, Université Pierre et Marie Curie, Paris, France, 1997. 
Lin, Y. L., Farley, R. D., and Orville, H. D.: Bulk parameterization of the snow field in a cloud model, J. Clim. Appl. Meteorol., 22, 1065-1092, 1993.

Martensson, E. M., Nilsson, E. D., de Leeuw, G., Cohen, L. H., and Hansson, H.-C.: Laboratory simulations and parameterization of the primary marine aerosol production, $\mathrm{J}$. Geophys. Res.-Atmos., 108, AAC 15-1-AAC 15-12, doi:10.1029/2002JD002263, 2003.

Monahan, E. C., Spiel, D. E., and Davidson, K. L.: A model of marine aerosol generation via whitecaps and wave disruption, in: Oceanic Whitecaps and their role in air/sea exchange, edited by: Monahan, E. C. and Mac Niocaill, G., Reidel, Norwell, Mass., USA, 167-174, 1986.

Nenes, A, Pilinis, C., and Pandis, S. N.: Continued Development and Testing of a New Thermodynamic Aerosol Module for Urban and Regional Air Quality Models, Atmos. Environ., 33, 1553-1560, 1999.

Otte, T. L. and Pleim, J. E.: The Meteorology-Chemistry Interface Processor (MCIP) for the CMAQ modeling system: updates through MCIPv3.4.1, Geosci. Model Dev., 3, 243-256, doi:10.5194/gmd-3-243-2010, 2010.

Otte, T. L., Pouliot, G., Pleim, J. E., Young, J. O., Schere, K. L., Wong, D. C., Lee, P. C. S., Tsidulko, M., McQueen, J. T., Davidson, P., Mathur, R., Chuang, H. Y., DiMego, G., and Seaman, N. L.: Linking the Eta model with the Community Multiscale Air Quality (CMAQ) modeling system to build a national weather forecasting system, Weather Forecast., 20, 3673842005.

Pleim, J. E. and Xiu, A.: Development of a land surface model, Part II: data assimilation, J. Appl. Meteorol., 42, 1811-1822, 2003.

Pleim, J. E. and Gilliam, R.: An indirect data assimilation scheme for deep soil temperature in the Pleim-Xiu land surface model, J. Appl. Meteorol. Clim., 48, 1362-1376, 2009.

Poppe, D., Andersson-Sköld, Y., Baart, A., Builtjes, P. J. H., Das, M., Fiedler, F., Hov, O., Korchner, F., Kuhn, M., Makar, P. A., Milford, J. B., Roemer, M. G. M., Runhke, R., Simpson, D., and Stockwell, W. R.: Gas-Phase reactions in atmospheric chemistry and transport models, Tech Rep. Garmisch-Partenkirchen, Germany: Eurotrac report, 1996.

Poupkou, A., Giannaros, T., Markakis, K., Kioutsioukis, I., Curci, G., Melas, D., and Zerefos, C.: A model for European Biogenic Volatile Organic Compound emissions: Software development and first validation, Environ. Model. Softw., 25, 1845-1856, doi:10.1016/j.envsoft.2010.05.004, 2010.

Ritter, B. and Geleyn, J. F.: A comprehensive radiation scheme for numerical weather prediction models withpotential applications in climate simulations, Mon. Weather Rev., 120, 303-325, doi:10.1175/1520-0493(1992)120<0303:ACRSFN>2.0.CO;2, 1992. 
Sarwar, G., Appel, K. W., Carlton, A. G., Mathur, R., Schere, K., Zhang, R., and Majeed, M. A.: Impact of a new condensed toluene mechanism on air quality model predictions in the US, Geosci. Model Dev., 4, 183-193, doi:10.5194/gmd-4-183-2011, 2011.

Sauter, F., Swaluw, E. van der, Manders-Groot, A., Wichink Kruit, R., Segers, A., and Eskes, H.: LOTOS-EUROS v1.8 Reference Guide, TNO Report TNO-060-UT-2012-01451, Utrecht, the Netherlands, 2012.

Schaap, M., Sauter, F., Timmermans, R. M. A., Roemer, M., Velders, G., Beck, J., and Builtjes, P.: The LOTOS-EUROS model: description, validation and latest developments, Int. J. Environ. Pollut., 32, 270-290, 2008.

Schaap, M., Manders, A., Hendriks, E., Cnossen, J., Segers, A., Denier van der Gon, H., Jozwicka, M., Sauter, F., Velder, G., Matthijsen, J., and Builtjes, P.: Regional Modelling of Particulate Matter for the Netherlands, Technical background report BOP, report 500099008, Netherlands Environmental Assessment Agency, 2009.

Schaettler, U., Doms, G., and Schraff, C.: A Description of the Nonhydrostatic Regional COSMO-Model Part VII: User’s Guide, Tech. rep., Deutscher Wetterdienst, 2008.

Schrodin, R. and Heise, E.: The multi-layer-version of the DWD soil model TERRA/LM,Tech. Rep., No. 2, Consortium for Small-Scale Modelling (COSMO), available at: http://www2.cosmomodel.org/content/model/documentation/techReports/docs/techReport02.pdf, 2001.

Seifert, A. and Beheng, K. D.: A double-moment parameterization for simulating autoconversion, accretion and selfcollection, Atmos. Res., 59-60, 265-281, doi:10.1016/S0169-8095(01)00126-0, 2001.

Shrivastava, M., Fast, J., Easter, R., Gustafson Jr., W. I., Zaveri, R. A., Jimenez, J. L., Saide, P., and Hodzic, A.: Modeling organic aerosols in a megacity: comparison of simple and complex representations of the volatility basis set approach, Atmos. Chem. Phys., 11, 66396662, doi:10.5194/acp-11-6639-2011, 2011.

Skamarock, W. C., Klemp, J. B., Dudhia, J., Gill, D. O., Barker, D. M., Duda, M. G., Huang, X.-Y., Wang, W., and Powers, J. G.: A description of the Advanced Research WRF version 3, National Center for Atmospheric Research Tech. Note, NCAR/TN-475CSTR, 113 pp., 2008.

Soares, J., Sofiev, M., and Hakkarainen, J.: Uncertainties of wildland fires emission in AQMEII phase 2 case study, Atmos. Environ., 115, 361-370, doi:10.1016/j.atmosenv.2015.01.068, 2015.

Sofiev, M.: A model for the evaluation of long-term airborne pollution transport at regional and continental scales, Atmos. Environ., 34, 2481-2493, doi:10.1016/S1352-2310(99)00415$\mathrm{X}, 2000$. 
Sofiev, M., Soares, J., Prank, M., de Leeuw, G., and Kukkonen, J.: A regional-to-global model of emission and transport of sea salt particles in the atmosphere, J. Geophys. Res., 116, D21302, doi:10.1029/2010JD014713, 2011.

Sofiev, M., Vira, J., Kouznetsov, R., Prank, M., Soares, J., and Genikhovich, E.: Construction of the SILAM Eulerian atmospheric dispersion model based on the advection algorithm of Michael Galperin, Geosci. Model Dev., 8, 3497-3522, doi:10.5194/gmd-8-3497-2015, 2015.

Stockwell, W. R., Kirchner, F. K., Kuhn, M., and Seefeld, S.: A new mechanism for regional atmospheric chemistry modeling, J. Geophys. Res., 102, 25847-25879, doi:10.1029/97JD00849, 1997.

Stockwell,W. R., Middleton, P., Chang, J. S., and Tang, X.: The second generation regional acid deposition model chemical mechanism for regional air quality modeling, J. Geophys. Res. 95, 16343e16367, doi:10.1029/JD095iD10p16343, 1990.

Tiedtke, M.: A comprehensive mass flux scheme for cumulus parameterization in large-scale models, Mon. Weather Rev., 117, 1779-1800, 1989.

Tuccella, P., Curci, G., Grell, G. A., Visconti, G., Crumeyrolle, S., Schwarzenboeck, A., and Mensah, A. A.: A new chemistry option in WRF-Chem v. 3.4 for the simulation of direct and indirect aerosol effects using VBS: evaluation against IMPACT-EUCAARI data, Geosci. Model Dev., 8, 2749-2776, doi:10.5194/gmd-8-2749-2015, 2015.

Walcek, C. J. and Taylor, G. R.: A theoretical method for computing vertical distributions of acidity and sulfate production within cumulus clouds, J. Atmos Sci., 43, 339-355, doi:0.1175/1520-0469(1986)043< 0339:ATMFCV>2.0.CO;2, 1986.

Whitten, G. Z., Heo, G., Kimura, Y., McDonald-Buller, E., Allen, D. T., Carter, W. P. L., and Yarwood, G.: A new condensed toluene mechanism for Carbon Bond: CB05-TU, Atmos. Environ., 44, 5346-5355, 2010.

Yarwood, G., Rao, S., Yocke, M., and Whitten, G.: Updates to the Carbon Bond Chemical Mechanism: CB05, Final Report to the US EPA, RT-0400675, available at: http://www.camx.com/files/cb05_final_report_120805.aspx, 2005.

Zare, A., Christensen, J. H., Gross, A., Irannejad, P., Glasius, M., and Brandt, J.: Quantifying the contributions of natural emissions to ozone and total fine PM concentrations in the Northern Hemisphere, Atmos. Chem. Phys., 14, 2735-2756, doi:10.5194/acp-14-2735-2014, 2014. 